\title{
An Ecological Assessment of Restoration Efforts Developed to Recover an Intensively Mined Appalachian Watershed
}

Andrew S. Watson

West Virginia University

Follow this and additional works at: https://researchrepository.wvu.edu/etd

\section{Recommended Citation}

Watson, Andrew S., "An Ecological Assessment of Restoration Efforts Developed to Recover an Intensively Mined Appalachian Watershed" (2014). Graduate Theses, Dissertations, and Problem Reports. 352.

https://researchrepository.wvu.edu/etd/352

This Thesis is protected by copyright and/or related rights. It has been brought to you by the The Research Repository @ WVU with permission from the rights-holder(s). You are free to use this Thesis in any way that is permitted by the copyright and related rights legislation that applies to your use. For other uses you must obtain permission from the rights-holder(s) directly, unless additional rights are indicated by a Creative Commons license in the record and/ or on the work itself. This Thesis has been accepted for inclusion in WVU Graduate Theses, Dissertations, and Problem Reports collection by an authorized administrator of The Research Repository @ WVU. For more information, please contact researchrepository@mail.wvu.edu. 
An Ecological Assessment of Restoration Efforts Developed to Recover an Intensively Mined Appalachian Watershed

Andrew S. Watson

\begin{abstract}
A Thesis submitted to
The Davis College of Agriculture, Natural Resources and Design

at West Virginia University

in partial fulfillment of the requirements

for the degree of

Master of Science

in

Wildlife and Fisheries Resources
\end{abstract}

George T. Merovich, Jr., Ph.D., Chair

J. Todd Petty, Ph.D.

Brady Gutta, M.S.

Wildlife and Fisheries Resources Program

Division of Forestry and Natural Resources

Morgantown, WV

2014

Key words: acid mine drainage (AMD), adaptive watershed management, biological communities, field experiment, water chemistry, and watershed restoration

Copyright 2014 Andrew S. Watson 


\section{ABSTRACT \\ An Ecological Assessment of Restoration Efforts Developed to Recover an Intensively Mined Appalachian Watershed}

\section{Andrew S. Watson}

Assessments of watershed-based restoration efforts are rare. Monitoring of projects preand post-treatment are essential for the science of stream restoration ecology to advance. We took an experimental approach, following adaptive watershed management principles, to evaluate the effectiveness of watershed-based restoration efforts developed to maximize the ecological recovery of acid mine drainage (AMD) impaired streams. We sampled water chemistry, physical habitat, and benthic macroinvertebrate and fish community structure in 3 stream types: AMD (14 streams), AMD-treated (13 streams), and unimpaired reference (4 streams). Treatment technology implemented on impaired streams included in-stream active treatment dosers, limestone sand applications, and an at-source passive treatment system. Assessment sites were strategically selected based on treatment locations, and we evaluated conditions pre-treatment and 3 years post-treatment. Water chemistry varied widely. Sites impaired by AMD improved in water quality with AMD treatment. For example, dissolved metals and acidity declined but treatment waters remained elevated in sulfate and conductivity. Likewise, biotic conditions varied widely and sites impaired by AMD improved in bio-condition scores with AMD treatment. For example, EPT genera increased but were still low compared to unimpaired stream types. In addition, we found fish at 9 sites that previously had none. Community-level analyses indicated improved but altered assemblage of taxa at treated sites compared to untreated sites. Overall, general improvements in water quality and bio-condition at the stream-scale were associated with improvements in a measure of ecological value at the watershed scale. Our results suggest that unique communities driven by the new water chemistry signature are being formed. Only 3 years have passed since project completion and communities that reflect true reference may require more time. This general framework for adaptive watershed management developed for mined watersheds can also be applied to other anthropogenic impacted watersheds in this region. Applying an experimental approach towards restoration project assessments can facilitate restorationists and project managers to understand what types of treatment accomplish their goals. 


\section{Acknowledgements}

I would like to thank my graduate committee, Dr. George T. Merovich, Jr., Dr. J. Todd Petty, and Brady Gutta for investing their time and energy in maturing my science. I would especially like to thank Dr. George T. Merovich, Jr. for being an exceptional mentor. His willingness and availability was and continues to be pivotal in guiding my research and teaching skills. I would also like to thank Dr. J. Todd Petty for allowing me the opportunity to participate in the WVU PCMI Program. Additionally, I would like to thank the Petty Lab. Specifically, Donna Hartman, Eric Miller, Eric Merriam, Brock Huntsman, Alison Anderson, and Brian Carlson. Without their continual support and camaraderie both inside and outside of the laboratory my time at WVU would not have been as enjoyable. I hope all of my friendships made with colleagues and faculty at WVU will continue to evolve, and that opportunities may arise to collaborate on future research projects. 


\section{Table of Contents}

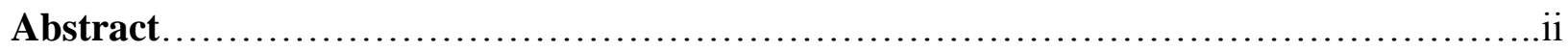

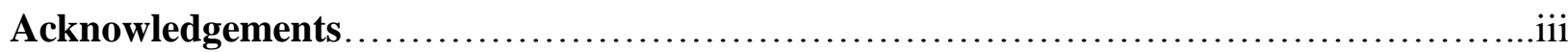

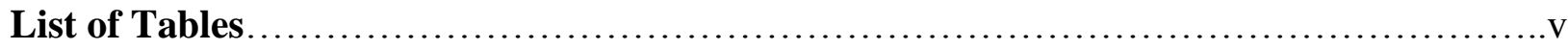

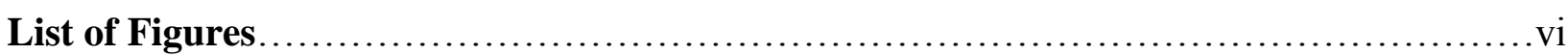

Chapter 1: Introduction and Executive Summary .......................................

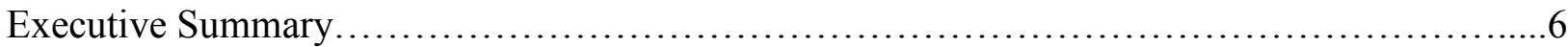

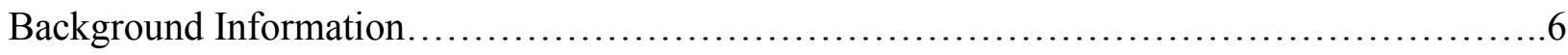

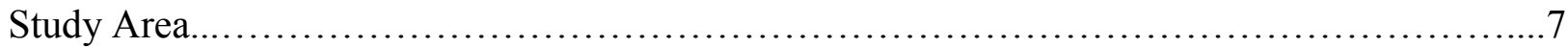

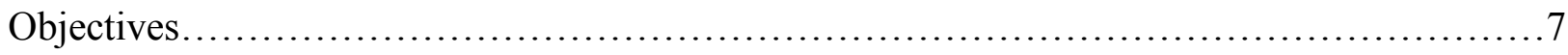

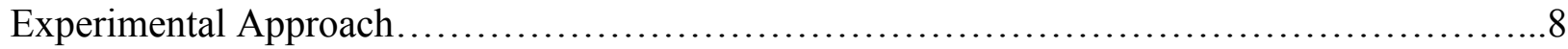

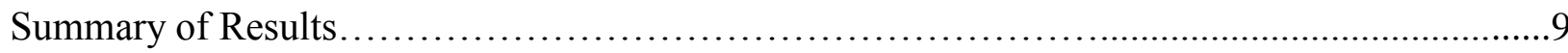

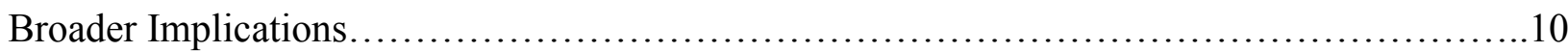

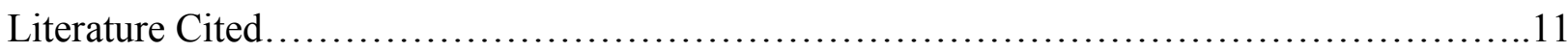

Figures and Tables........................................................................

Chapter 2: An Ecological Assessment of Restoration Efforts Developed to Recover an Intensively Mined Appalachian Watershed .............................................. 18

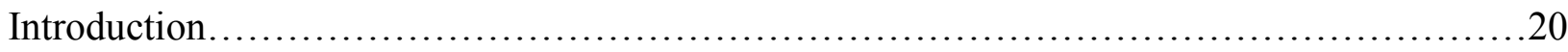

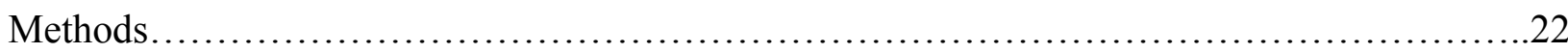

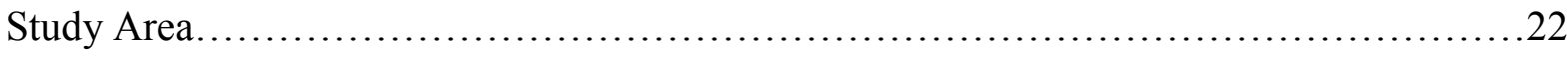

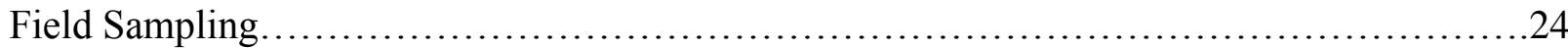

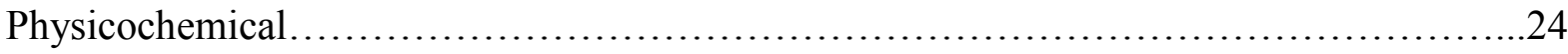

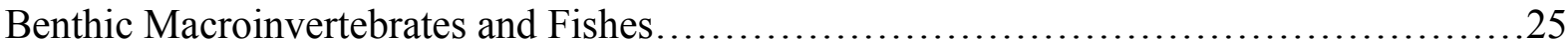

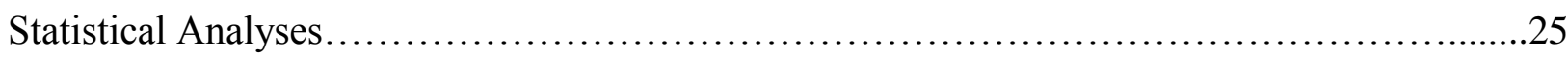

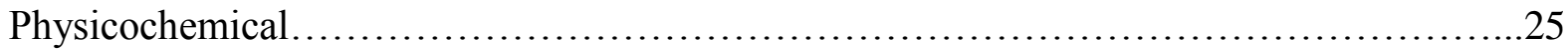

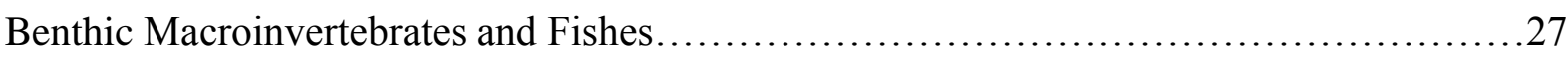

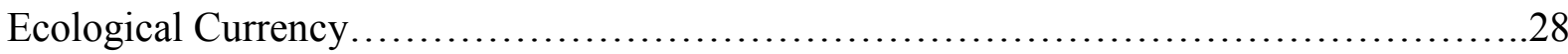

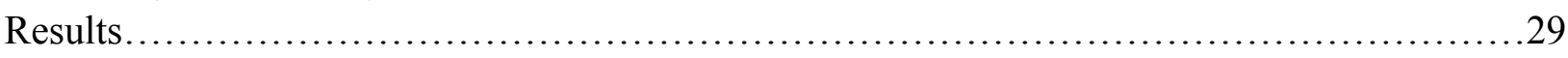

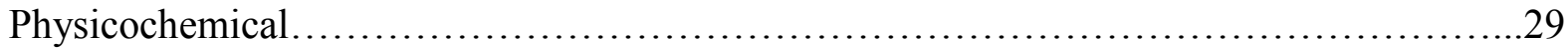

Benthic Macroinvertebrates and Fishes................................................ 30

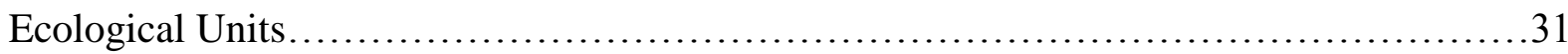

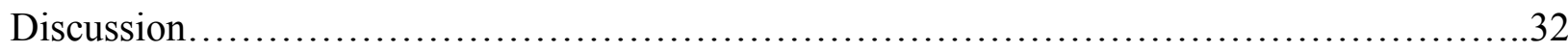

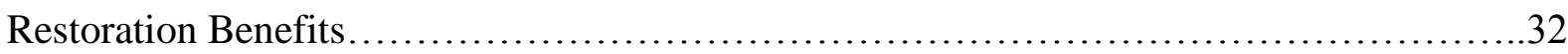

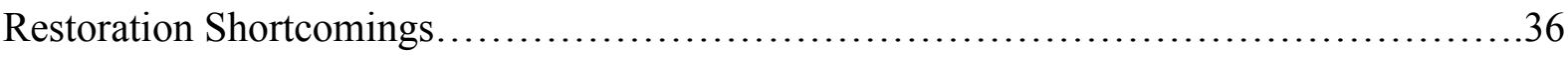

Implications for Watershed-based Restoration Programs................................ 37

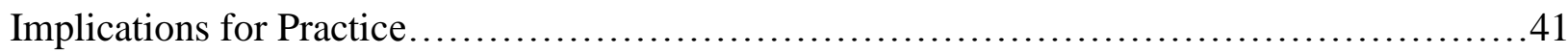

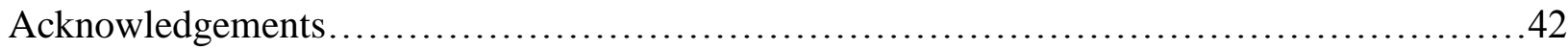

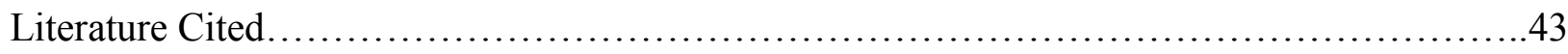

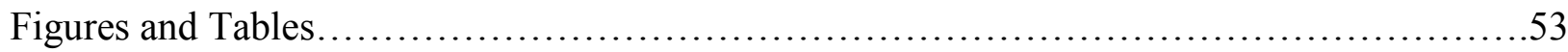




\section{List of Tables}

\section{Chapter 1}

Table 1. Site names, site abbreviations, GPS coordinates of sampling locations, stream type, and treatment technology implemented. "_" $=$ na, L.S. Sand = limestone sand, I.S. Doser = in-stream

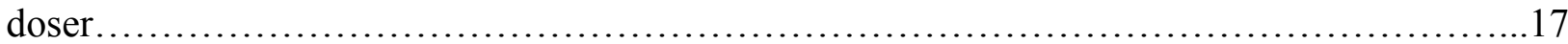

\section{Chapter 2}

Table 1. Site names, site abbreviations, GPS coordinates of sampling locations, stream type, and treatment technology implemented. "“"“=na, L.S. Sand = limestone sand, I.S. Doser = in-stream

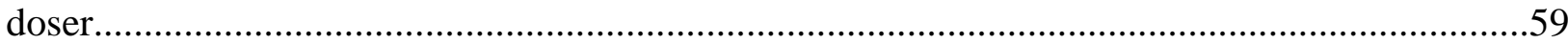

Table 2. Means and standard deviations of water chemistry parameters and principal component (PC) 1, 2, 3, and 4 scores for each stream type. Water chemistry constituent means with different letters are statistically different from one another $(\mathrm{p}<0.05$; analysis of variance, Tukeys posttest). Means are reported in $\mathrm{mg} / \mathrm{L}$. Conductivity is reported in $\mu \mathrm{S} / \mathrm{cm}$, and alkalinity is reported in $\mathrm{mg} / \mathrm{L} \mathrm{CaCO}_{3}$ equivalents................................................60

Table 3. Acid, alkalinity, and net acidity loads pre- (2008) and post-treatment (2013) at the mouth of the watershed and major tributaries that received treatment (values in tons/yr $\mathrm{CaCO}_{3}$ equivalents. $\Delta$ net acidity negative values indicate decline...............................61

Table 4. Means and standard deviations of benthic macroinvertebrate and fish metrics for each stream type. Metric means with different letters are statistically different from one another ( $\mathrm{p}<$ 0.05; analysis of variance, Tukeys post-test). WVSCI = West Virginia Stream Condition Index, GLIMPSS = Genus Level Index of Most Probable Stream Status, EPT = Ephemeroptera, Plecoptera, Trichoptera, I-P = Invertivore-Piscivore ..................................62

Table 5. EUs downstream of treatment sites, and at the mouth of the watershed before and after project completion 


\section{List of Figures}

\section{Chapter 1}

Figure 1. Map of Abram Creek watershed in West Virginia's eastern panhandle along with AMD-treatment locations and assessment sites.......................................... 16

\section{Chapter 2}

Figure 1. Map of Abram Creek watershed in West Virginia's eastern panhandle along with AMD-treatment locations and assessment sites..........................................5

Figure 2. Bivariate scatter plot of principle component (PC) 1 and 2 scores for each water chemistry sample overlaid with stream type. $\mathrm{A}=$ acid mine drainage (AMD), $\mathrm{T}=$ treated, and $\mathrm{R}$ $=$ reference water quality types. Chemical parameters with high $(>|0.5|)$ factor loadings on each $\mathrm{PC}$ are shown on the corresponding axis. $\mathrm{SO}_{4}=$ sulfate; Cond $=$ specific conductivity.

Figure 3. Nonmetric multidimensional scaling (NMDS) ordination of benthic macroinvertebrate samples (Bray-Curtis distance coefficient) in 2 dimensions showing sites labeled by stream type (A), water chemistry vectors (B), macroinvertebrate metrics (C), and weighted mean positions of selected taxa (D). Stress $=0.15$ in the 3-dimensional solution. Stream type abbreviations as in Fig. 2. Alk = alkalinity, Cond $=$ specific conductivity, PerDom $=\%$ dominance, PerE $=\%$ Ephemeroptera, PerChiron $=\%$ Chironomidae, EPT $=$ Ephemeroptera, Plecoptera, Trichoptera, GRICH = genus-level richness, WVSCI = West Virginia Stream Condition Index (a family-level multimetric index of biotic integrity), GLIMPSS = Genus Level Index of Most Probable Stream Status (a genus-level multimetric index of biotic integrity). ADONIS p-value $=0.004 \ldots \ldots \ldots \ldots 55$

Figure 4. Nonmetric multidimensional scaling (NMDS) ordination of fish samples (Bray-Curtis distance coefficient) in 2 dimensions showing sites labeled by stream type (A), water chemistry vectors (B), fish metrics (C), and weighted mean positions of selected species (D). Stress $=0.11$ in the 2-dimensional solution. Stream type abbreviations as in Fig. 2. Cond = specific conductivity, BenthicSpp = \# of benthic species, ProTol = proportion tolerant, SRICH = specieslevel richness. SenSRICH = sensitive species richness, ProI.P = proportion of invertivorepiscivores, ProM.O = proportion of macro-omnivores, ProGSpawn = proportion of gravel spawning species, SEAT = Semotilus atromaculatus (creek chub), SAFO = Salvelinus fontinalis (brook trout), ETFL = Etheostoma flabellare (fantail darter), COCA = Cottus caeruleomentum (blue ridge sculpin), RHAT = Rhinichthys atratulus (eastern blacknose dace), CACO = Catostomus commersonii (white sucker), LECY = Lepomis cyanellus (green sunfish), MIDO = Micropterus dolomieu (smallmouth bass), CAAN = Campostoma anomalum (stoneroller),

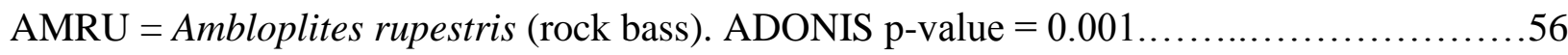


Figure 5. Percent cumulative EUs along the Abram Creek mainstem from the headwaters to the mouth pre- (2008) and post-treatment (2013). Arrows represent major tributaries entering the mainstem at their respective river kilometer and treatment type............................57

Figure 6. Map illustrating segment-level watershed WVSCI scores pre- (2008) and posttreatment (2013) throughout the Abram Creek watershed...................................58 



\section{Chapter 1: Introduction and Executive Summary - An Ecological Assessment of Restoration Efforts Developed to Recover an Intensively Mined Appalachian Watershed}

Stream restoration projects are becoming increasingly popular in an effort to alleviate the negative impacts associated with anthropogenic landscape change. As the human population continues to increase, resource consumption, energy demands, and infrastructure advancements continue to place additional stress on aquatic ecosystems. As a consequence, we must decide whether to alter these societal demands, or rely on our ability to create, restore, and enhance aquatic ecosystems and their services (Hilderbrand et al. 2005). The most common types of stream and river restoration projects in the United States have goals oriented towards improving water quality, riparian zones, in-stream habitat, fish passage, and bank stabilization (Bernhardt et al. 2005). The underlying theme of my thesis research is watershed restoration ecology - the idea that the transformation of previously degraded stream ecosystem habitats into ecologically functioning habitats, will serve a major societal benefit both ecologically and economically.

The 3 key components of restoration are the chemical and physical features of the habitat and the species that reside in the environment (Bradshaw 1996). Efforts should always focus on the restoration of functions and processes, because without these species and communities cannot persist (Bradshaw 1996). Nevertheless, many stream restoration projects fail to meet the expected results in regards to aquatic community assemblages (Sundermann et al. 2011). In an evaluation of 78 river restoration projects, Palmer et al. (2010) note only 2 that show statistically significant improvements in benthic macroinvertebrate diversity. It is well known that the science of riverine restoration suffers from lack of evaluation (Palmer et al. 2005). Projects that are evaluated tend to be measured by diversity-based bioassessment techniques used to determine the success or failure of projects (Brown et al. 2011). Therefore, even though stream 
restoration may be an effective means in rebuilding a local environment, it may remain disconnected from the populations and communities it was meant to support (Brown et al. 2011).

Freund and Petty (2007) emphasize that for remediation programs to be successful they must focus on restoring the connectivity among stream reaches within the entire dendritic ecological network. This concept is well documented in the literature (Freund and Petty 2007, Jansson et al. 2007, Lake et al. 2007, McClurg et al. 2007). Restoring the connectivity of stream reaches within a watershed is vital for the recovery of biological communities. In theory, restoration efforts aimed at increasing watershed connectivity should allow for the full movement and recolonization potential of both fish and aquatic invertebrates (McClurg et al. 2007). To promote the recovery of interconnected stream networks, restoration programs must transition restoration efforts from the local scale to the watershed scale.

Bernhardt et al. (2005) state that most restoration projects are small scale, being carried out on stream segments less than $1 \mathrm{~km}$ in length. These restoration efforts are focused on improving environmental conditions at the local (segment-level) scale. Historically, local scale projects commonly fell victim to the "field of dreams" myth (Hilderbrand et al. 2005). This assumption that "if you build it they will come" focuses entirely on the local scale ignoring processes occurring in the broader context, such as the connectivity between metacommunities (Merovich et al. 2013). If barriers to dispersal exist at the regional scale, colonizers will be unable to access the newly acquired habitat, which if assessed based on biological community composition may be deemed a restoration failure. Metacommunity theory suggests that "if you build it, they may not come" (Brown et al. 2011).

Reestablishing the connectivity between stream reaches within the entire dendritic ecological network is essential for successful stream restoration projects evaluated by 
biodiversity assessment techniques. By incorporating local (segment-level) and regional (watershed) information into a holistic watershed-based restoration program, and taking into account the position of the project in regards to its surrounding, a better understanding of the outcome of restoration projects with respect to aquatic community assemblages should be achieved. This is likely considering that local communities are a product of the regional species pool (Sundermann et al. 2011). By sampling populations and communities within a region (i.e. watershed), the regional species pool can be captured and integrated into the future restorability of the program.

My research in watershed restoration ecology is primarily concerned with restoring the chemical integrity of streams impacted by acid mine drainage (AMD) from legacy coal mining. The chemical composition of our water tells the story of our landscape and is a direct reflection of our society. AMD occurs when sulfide minerals, such as pyrite, are oxidized (Battaglia et al. 2005). Natural resource extraction such as coal mining exposes large amounts of sulfide minerals to air and water (Brenner et al. 1995). The sulfide left behind as waste rock accumulates and is oxidized rapidly by the atmosphere (Andrews et al. 2004). Oxidation also occurs when abandoned mine lands (AMLs) are flooded after mining operations discontinue. The oxidation of sulfide minerals produces sulfuric acid along with other dissolved metals such as iron, manganese, and aluminum (Andrews et al. 2004). When these acidic drainages enter streams they pose a major potential source of pollution to aquatic ecosystems (Brenner et al. 1995). Further down the stream continuum, as $\mathrm{pH}$ increases, metal precipitation occurs. When metal precipitation occurs, the substrate of the streambed is often left coated with metal flocculants. These metal flocculants can be toxic to aquatic life. Additionally, they can degrade aquatic 
systems by lowering oxygen concentrations and making substrate uninhabitable for most benthic macroinvertebrates (Brenner et al. 1995, MacCausland and McTammany 2007).

A considerable amount of research and development has been done on acid impacted watersheds to understand and reduce the effects of mining on aquatic ecological conditions in Appalachia (Freund and Petty 2007, Merovich and Petty 2007, Merovich et al. 2007, Petty et al. 2008, Petty et al. 2010). Treatment technologies implemented on impacted streams include active and passive systems. Historically, passive treatment systems have been the preferred method of AMD remediation (Coberly and Rice 2013). Passive treatment is usually limestone based occurring at or near the source of AMD. Systems are generally designed to last for 20 years with no additional operation and maintenance costs after the initial installation. Specific passive treatment systems include anoxic limestone drains, anaerobic and aerobic wetlands, successive alkaline-producing systems, and alkaline leach beds to name a few. In a recent study by Coberly and Rice (2013), passive treatment systems were assessed by the WV AML program for their overall success. They observed an initial improvement in water chemistry parameters at a majority of systems after installation, but found that sites frequently returned to pre-treatment conditions after only a few years.

Active treatment technologies also utilize chemicals for AMD abatement. The difference from passive treatment is that additional costs associated with operation and maintenance are needed to replenish chemicals used in treatment. Types of active treatment include limestone sand application and in-stream dosers. Limestone sand application is performed by dumping sand along the impacted tributary's stream bank where gravity and stream water gradually wash the sand downstream. An in-stream doser treats AMD by diverting some of the water from the impacted tributary to power the doser by utilizing either a water wheel or tipping bucket that 
drives an auger and doses the stream with alkaline material. The treated water then returns to the stream where precipitation reactions occur.

In the United States alone, an average of $\$ 1$ billion dollars per year has been spent on river restoration projects since 1990 (Bernhardt et al. 2005). Surprisingly with all of this money being invested into riverine restoration projects there are no agreed upon standards for what constitutes restoration success (Palmer et al. 2005) and assessment of such projects are rare (Bernhardt et al. 2005, Palmer et al. 2005, Heinrich et al. 2014).

My interest in watershed restoration ecology stems from the fact that fresh water lotic systems are incredibly dynamic, complex, and captivating ecosystems. Fresh water resources are renewable, but finite, and a prerequisite for all forms of life. The growing scarcity of water is a universal concern and product of the increasing human population. With human water consumption exceeding sustainable levels, evident through groundwater depletion, low or nonexistent stream flows, and increasing pollution levels (Postel 2000), the need to protect, conserve, and restore our fresh water resources is fundamental in ensuring the health of our lives, future generations, and societal advances. My current research involves evaluating the effectiveness of watershed-based restoration efforts developed to maximize the ecological recovery of AMD-impaired streams in the Abram Creek watershed, a sub-watershed of the North Branch of the Potomac River basin. Not only will this research provide baseline remediation data for the assessment of progress towards implementing the master plan of the Abram Creek watershed restoration project, but these results will also enable the West Virginia Department of Environmental Protection (WVDEP), the Division of Land Restoration, and the Office of Abandoned Mine Land and Reclamation to improve the overall remediation program. This research is critical to advancing holistic watershed management plans that will facilitate other 
water resource management agencies in the future. Without long-term monitoring of restoration efforts from particular management experiments, valuable knowledge is lost (Cushing and Allan 2001). This knowledge is crucial towards advancing the science of watershed restoration ecology, as well as for directing allocations of funds towards projects that are likely to succeed.

\section{Executive Summary}

\section{Background Information}

There is a critical need for the assessment and evaluation of watershed-based restoration efforts developed to maximize the ecological recovery of AMD-impaired streams in mined central Appalachian watersheds. AMD from abandoned mine lands (AMLs) has remained a well-posed problem associated with mining. This acidification of surface and groundwater is a persistent environmental issue with global dimensions (Bott et al. 2012). In central Appalachia, the effects of coal mining on flowing waters may be one of the most crucial environmental issues in the United States (Petty et al. 2010). In this region of the world, coal has been mined for nearly 200 years (Merovich et al. 2007), and as a result, more than 17,000 km of streams in the Mid-Atlantic Highlands are impacted by AMD (USEPA 2000). The underlying geology of north central West Virginia (WV) is rich in pyrite, with prevailing coal seams comprising upper and lower Freeport, upper and lower Kittanning, Pittsburgh, and Bakerstown (Petty et al. 2010). The acidic drainages created from mining here are crippling to the ecological and economic benefits of streams throughout WV and the entire Appalachian region (Petty et al. 2008). 


\section{Study Area}

A strategic watershed-based restoration plan, following adaptive watershed management principles, went online for the Abram Creek watershed in 2010 to mitigate the effects of AMD. Abram Creek is a 115- $\mathrm{km}^{2}$ watershed (North Branch/Potomac River basin) located in West Virginia's eastern panhandle in Grant and Mineral Counties (lat 39¹8'44.8”, long 79¹2'41.2”). The mainstem is $31.5 \mathrm{~km}$ long, and joins the North Branch of the Potomac River near Kitzmiller, Maryland. Land cover is dominated by forest (66\%) and agriculture (25\%). The geology of the watershed consists predominantly of shale and sandstone. The watershed contains 23 subwatersheds, the largest of which are Emory Creek, Glade Run, Johnnycake Run, and Laurel Run (Figure 1). Impairments throughout the watershed are primarily due to AMD from AMLs (WVWRI 2007). WVDEP's Division of Water and Waste Management identified 27 abandoned mine sources (discharges, seeps, portals, culverts, refuse piles, diversion ditches, and ponds) throughout the study area (WVWRI 2007). There are 8 NPDES permits in the watershed for metal effluents related to mining (WVWRI 2007). The AMD-treatment technology implemented in the restoration plan includes 3 in-stream active treatment dosers at the Abram Creek headwaters, Little Creek, and an unnamed tributary (Morgan 25 site) at river kilometer 6.2; 2 limestone sand dump sites at Laurel Run and Emory Creek; and 1 passive treatment system at Glade Run (Figure 1, Table 1).

\section{Objectives}

The principal objective of my research was to assess the effectiveness of watershed-based restoration plans developed to maximize the ecological recovery of AMD-impaired streams. This post-restoration assessment is an essential step in completing the adaptive watershed 
management cycle. Since this cyclical process is adaptive, such base-line remediation data can be used to improve the overall restoration plan. The updated, post-restoration dataset can be used by water resource management agencies to adjust the number of treatment locations, and improve design of existing technologies. The specific objectives of this research were to: 1 ) quantify the response of water chemistry, benthic macroinvertebrates, and fishes to AMDtreatment 3 years after restoration efforts were implemented; and 2) calculate a measure of ecological value to quantify the putative benefits of restoration efforts at the watershed scale.

\section{Experimental Approach}

In this research I took an experimental approach. Existing data from sites sampled in 2008, by the Petty lab, were used to quantify pre-restoration ecological conditions for comparison with the post-restoration data collected. I studied a total of 18 sites within the study area for water chemistry, biological conditions, and physical habitat conditions. Sites were strategically selected based on treatment locations to evaluate the presumed benefits of treatment (Figure 1). In 2008, before treatment, 14 sites were sampled. These same 14 sites were sampled again in 2013, after treatment. An additional 4 sites were sampled in 2013, after treatment, to characterize supplementary reference and untreated AMD streams within the study area.

I classified streams into 3 a priori types: AMD, treated, and reference. AMD streams were listed on the 2004 303d list for water quality and/or biological impairment (WVWRI 2007). Treated streams received AMD-treatment or were downstream of treatment. Reference streams were naturally circumneutral. Circumneutral streams within the study area represent the "best available conditions" in the watershed and provide the only reasonable reference condition against which to assess watershed-based restoration plans (Campbell 2000, McClurg et al. 2007). 
To quantify the response of these ecological conditions to treatment I used a variety of univariate and multivariate statistical procedures to analytically evaluate the ecological response to treatment. I also calculated a metric called ecological units (EUs), a weighted value in units of stream length, which represent the availability of ecologically functioning stream habitat (Petty and Throne 2005, Merovich and Petty 2007). This ecological currency allowed me to quantify and compare the ecological conditions pre- and post-treatment to determine if restoration efforts accrued ecological benefits at individual segment-level watersheds and if they accumulated at the watershed scale.

\section{Summary of Results}

I was able to complete the final step in the adaptive watershed management cycle for the Abram Creek watershed restoration plan. This post-restoration assessment showed significant improvements in biological diversity and water chemistry parameters at the watershed scale. These improvements were notably observed downstream of in-stream active treatment dosers and limestone sand dump sites throughout the watershed, with the exception of Laurel Run, which may have been compromised due to ongoing mining activity. I characterized the overall chemical response to AMD-treatment as a transition from metal laden acidic waters to hard waters with elevated sulfate concentrations and conductivity. Although this new water chemistry signature is a departure from reference conditions, biological communities are responding to these chemical improvements. Specifically, fish were found at 9 stream segments that previously had none, 2 of which had brook trout and 1 of which had smallmouth bass. Also, benthic macroinvertebrate scores increased statistically after treatment compared to before. Only 3 years have passed since project completion, and communities that reflect true reference may require more time. 


\section{Broader Implications}

This post-restoration assessment was the final step in completing the adaptive watershed management cycle. This adaptive management framework was developed for application to AML reclamation of intensively mined central Appalachian watersheds (Petty et al. 2008). This post-restoration assessment will enable the WVDEP, the Division of Land Restoration, and the Office of Abandoned Mine Land and Reclamation to improve the overall restoration plan for the Abram Creek Watershed Restoration Project. It will also facilitate other water resource management agencies when designing future watershed-based restoration plans for acid impacted watersheds. Transitioning restoration efforts from the local (segment-level) scale to the regional (watershed) scale can achieve significant improvements to ecological conditions and fisheries. This general framework for adaptive watershed management developed for mined watersheds can also be applied to other anthropogenic impacted watersheds in this region. Applying an experimental approach towards restoration project assessments can facilitate restorationists and project managers to understand what types of treatment accomplish their goals.

In the following chapter, I highlight the important findings and conclusions of the ecological assessment of restoration efforts developed to recover the Abram Creek watershed. The style has been formatted for a manuscript publication in the journal Restoration Ecology. The perspective is in first person plural due to the document being a collaborative effort. 


\section{Literature Cited}

Andrews J. E., P. Brimblecombe, T. D. Jickells, P. S. Liss, and B. J. Reid. 2004. An introduction to environmental chemistry. Blackwell Publishing, Malden, MA, USA.

Battaglia M., G. Hose, E. Turak, and B. Warden. 2005. Depauperate macroinvertebrates in a mine affected stream: Clean water may be the key to recovery. Environmental Pollution 138(1):132-141.

Bernhardt E. S., J. Follstad-Shah, D. Galat, S. Gloss, P. Goodwin, D. Hart, B. Hassett, R. Jenkinson, S. Katz, G. M. Kondolf, P. S. Lake, M. A. Palmer, R. Lave, J. L. Meyer, T. K. O'Donnell, L. Pagano, B. Powell, E. Sudduth, J. D. Allan, G. Alexander, K. Barnas, S. Brooks, J. Carr, S. Clayton, and C. Dahm. 2005. Synthesizing U.S. river restoration efforts. Science 308(5722):636-637.

Bott T. L., J. K. Jackson, M. E. Mctammany, J. D. Newbold, S. T. Rier, B. W. Sweeney, and J. M. Battle. 2012. Abandoned coal mine drainage and its remediation: Impacts on stream ecosystem structure and function. Ecological Applications 22(8):2144-2163.

Bradshaw A.D. 1996. Underlying principles of restoration. Canadian Journal of Fish and Aquatic Sciences 53(S1):3-9.

Brenner F. J., H. A. Gray, B. R. Porter, and V. A. Tilmans. 1995. Potential effects of mining contaminants on ecosystem function and human health. Pages 100-111 in S. K. Majumdar, E. W. Miller and F. J. Brenner, editors. Environmental contaminants, ecosystems and human health. The Pennsylvania Academy of Science, Easton, PA. 
Brown B. L., C. M. Swan, D. A. Auerbach, E. H. Campbell Grant, N. P. Hitt, K. O. Maloney, and C. Patrick. 2011. Metacommunity theory as a multispecies, multiscale framework for studying the influence of river network structure on riverine communities and ecosystems. Journal of the North American Benthological Society 30(1):310-327.

Campbell D. 2000. Using energy systems theory to define, measure, and interpret ecological integrity and ecosystem health. Ecosystem Health 6(3):181-204.

Coberly E. J., and R. Rice. 2013. WV AML in-stream dosing for treatment of AMD. West Virginia Department of Environmental Protection Office of Abandoned Mine Lands and Reclamation Charleston, WV.

Cushing C. E., and J. D. Allan. 2001. Streams their ecology and life. Academic Press, San Diego, CA, USA.

Freund J. G., and J. T. Petty. 2007. Response of fish and macroinvertebrate bioassessment indices to water chemistry in a mined Appalachian watershed. Environmental Management 39(5):707-720.

Heinrich K. K., M. R. Whiles, and C. Roy. 2014. Cascading ecological responses to an in-stream restoration project in a midwestern river. Restoration Ecology 22(1):72-80.

Hilderbrand R., A. Watts, and A. Randle. 2005. The myths of restoration ecology. Ecology and Society 10(1):19-29. 
Jansson R., C. Nilsson, and B. Malmqvist. 2007. Restoring freshwater ecosystems in riverine landscapes: the roles of connectivity and recovery processes. Freshwater Biology 52(4):589-596.

Lake P. S., N. Bond, and P. Reich. 2007. Linking ecological theory with stream restoration. Freshwater Biology 52(4):597-615.

MacCausland A., and M. E. McTammany. 2007. The impact of episodic coal mine drainage pollution on benthic macroinvertebrates in streams in the Anthracite region of Pennsylvania. Environmental Pollution 149(2):216-226.

McClurg S. E., J. T. Petty, P. M. Mazik, and J. L. Clayton. 2007. Stream ecosystem response to limestone treatment in acid impacted watersheds of the Allegheny plateau. Ecological Applications 17(4):1087-1104.

Merovich Jr G. T., J. T. Petty, M. P. Strager, and J. B. Fulton. 2013. Hierarchical classification of stream condition: A house-neighborhood framework for establishing conservation priorities in complex riverscapes. Freshwater Science 32(3):874-891.

Merovich Jr. G. T., and J. T. Petty. 2007. Interactive effects of multiple stressors and restoration priorities in a mined Appalachian watershed. Hydrobiologia 575(1):13-31.

Merovich Jr. G. T., J. M. Stiles, J. T. Petty, P. F. Ziemkiewicz, and J. B. Fulton. 2007. Water chemistry-based classification of streams and implications for restoring mined Appalachian watersheds. Environmental Toxicology and Chemistry 26(7):1361-1369. 
Palmer M. A., H. L. Menninger, and E. Bernhardt. 2010. River restoration, habitat heterogeneity and biodiversity: a failure of theory or practice? Freshwater Biology 55:205-222.

Palmer M. A., E. S. Bernhardt, J. D. Allan, P. S. Lake, G. Alexander, S. Brooks, J. Carr, S. Clayton, C. N. Dahm, J. F. Shah, D. L. Galat, S. G. Loss, P. Goodwin, D. D. Hart, B. Hassett, R. Jenkinson, G. M. Kondolf, R. Lave, J. L. Meyer, T. K. O'Donnell, L. Pagano, and E. Sudduth. 2005. Standards for ecologically successful river restoration. Journal of Applied Ecology 42(2):208-217.

Petty J. T., J. B. Fulton, M. P. Strager, G. T. Merovich Jr., J. M. Stiles, and P. F. Ziemkiewicz. 2010. Landscape indicators and thresholds of stream ecological impairment in an intensively mined Appalachian watershed. Journal of the North American Benthological Society 29(4):1292-1309.

Petty J. T., B. Gutta, R. Herd, J. Fulton, J. Stiles, M. Strager, J. Svetlick, and P. Ziemkiewicz 2008. Identifying cost-effective restoration strategies in mining impacted West Virginia watersheds. 25th Annual Meetings of the American Society of Mining and Reclamation and 10th Meeting of IALR 2008. Richmond, VA.

Petty J. T., and D. Thorne. 2005. An ecologically based approach to identifying restoration priorities in an acid-impacted watershed. Restoration Ecology 13(2):348-357.

Postel S. 2000. Entering an era of water scarcity: The challenges ahead. Ecological Applications 10(4):941-948. 
Sundermann A., S. Stoll, and P. Haase. 2011. River restoration success depends on the species pool of the immediate surroundings. Ecological Applications 21(6):1962-1971.

United States Environmental Protection Agency (USEPA). 2000. Mid-Atlantic Highlands streams assessment: final report / by Environmental Monitoring and Assessment Program, National Health and Environmental Effects Research Laboratory, Western Ecology Division, Office of Research and Development \& Region III. Philadelphia, PA.

West Virginia Water Research Institute (WVWRI), National Mine Land Reclamation Center, Watershed Technical Assistance Center, and West Virginia University. 2007. Abram Creek watershed restoration plan. West Virginia University Morgantown, WV. 
Figures and Tables

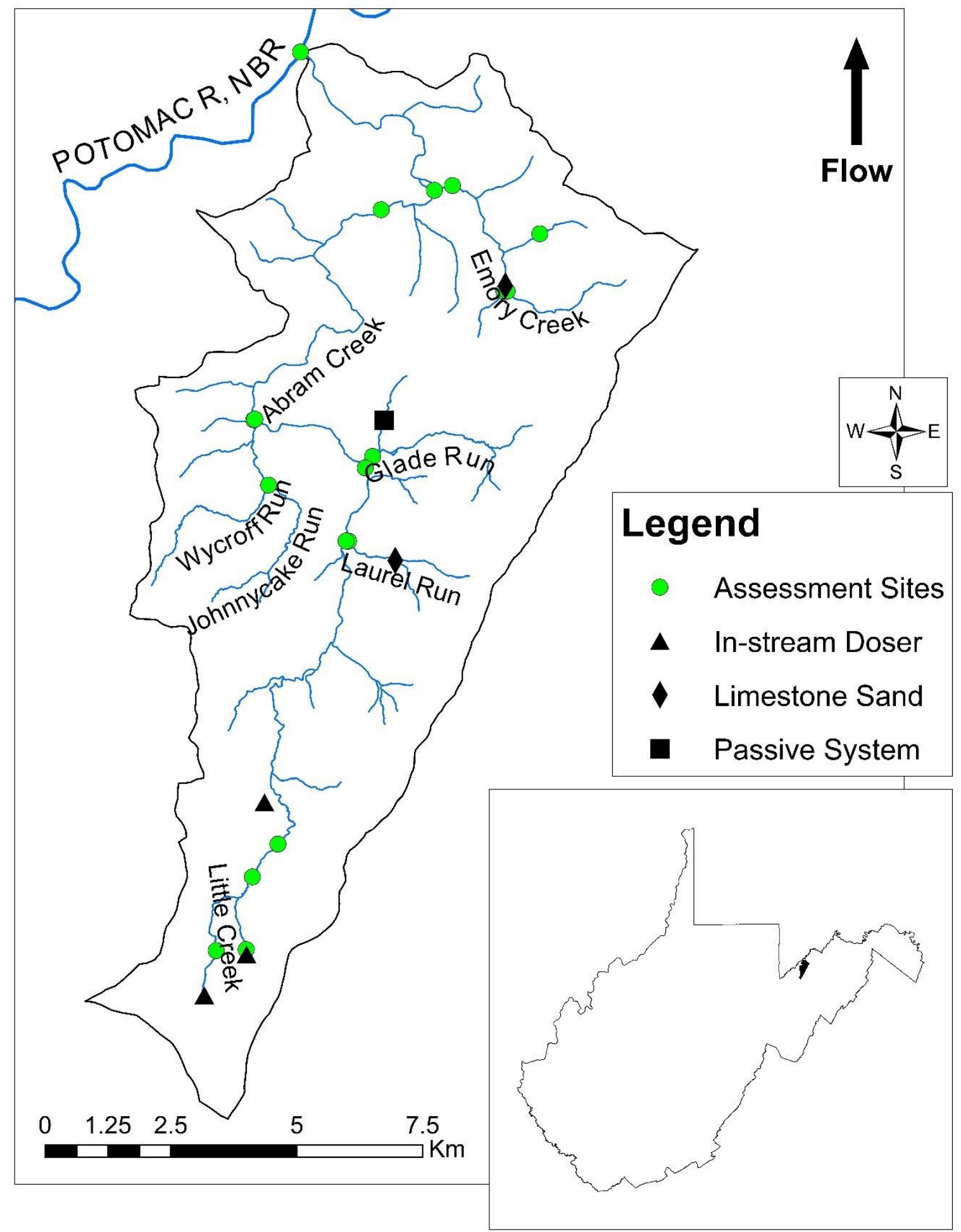

Figure 1. Map of Abram Creek watershed in West Virginia's eastern panhandle along with AMD-treatment locations and assessment sites. 
Table 1. Site names, site abbreviations, GPS coordinates of sampling locations, stream type, and treatment technology implemented. "_“= na, L.S. Sand = limestone sand, I.S. Doser = in-stream doser.

\begin{tabular}{|c|c|c|c|c|c|c|}
\hline Site Name & Site Abbrev. & Latitude & Longitude & $\begin{array}{c}\text { Stream Type } \\
2008 \\
\end{array}$ & $\begin{array}{c}\text { Stream Type } \\
2013 \\
\end{array}$ & $\begin{array}{c}\text { Treatment } \\
\text { Type }\end{array}$ \\
\hline Abram Creek at Mouth & AB MOUTH & 39.37938 & -79.20199 & AMD & Treated & - \\
\hline Abram Creek above Emory & AB ABV EM & 39.35369 & -79.17154 & AMD & Treated & - \\
\hline Emory Creek at Mouth & EMORY & 39.35429 & -79.16722 & AMD & Treated & L.S. Sand \\
\hline Unnamed Tributary 2 Emory Creek & UNT EMORY 2 & 39.33565 & -79.15524 & - & Reference & - \\
\hline Emory Creek Headwater Right Fork & EM HW RF & 39.33565 & -79.15599 & - & Reference & - \\
\hline Emory Creek Headwater Left Fork & EM HW LF & 39.33565 & -79.15524 & - & AMD & - \\
\hline Abram Creek at Laytons & AB LAT & 39.35058 & -79.18403 & AMD & Treated & - \\
\hline Johnnycake Run at Mouth & JC MOUTH & 39.31358 & -79.21424 & Reference & Reference & - \\
\hline Upper Johnnycake Run & JC UPPER & 39.30171 & -79.21109 & - & Reference & - \\
\hline Abram Creek above Johnnycake & AB ABV JC & 39.31370 & -79.21385 & AMD & Treated & - \\
\hline Glade Run at Mouth & GLADE & 39.30629 & -79.18667 & AMD & Treated & Passive \\
\hline Abram Creek above Glade & AB ABV GLD & 39.30453 & -79.18884 & AMD & Treated & - \\
\hline Laurel Run at Mouth & LAUREL & 39.29607 & -79.19072 & AMD & Treated & L.S. Sand \\
\hline Abram Creek above Laurel & AB ABV LAURL & 39.29654 & -79.19087 & AMD & Treated & - \\
\hline Abram Creek at Vindex & AB VIN & 39.23752 & -79.21071 & AMD & Treated & - \\
\hline Abram Creek at CR 42 & $\mathrm{AB}$ AT 42 & 39.23161 & -79.21660 & AMD & Treated & - \\
\hline Little Creek & AB HW LF & 39.21851 & -79.21824 & AMD & Treated & I.S. Doser \\
\hline Abram Creek Headwaters & AB HW RF & 39.21855 & -79.22520 & AMD & Treated & I.S. Doser \\
\hline
\end{tabular}




\title{
Chapter 2: An Ecological Assessment of Restoration Efforts Developed to Recover an Intensively Mined Appalachian Watershed
}

\author{
Abstract - Assessments of watershed-based restoration efforts are rare. Monitoring of \\ projects pre- and post-treatment are essential for the science of stream restoration ecology to \\ advance. We took an experimental approach, following adaptive watershed management \\ principles, to evaluate the effectiveness of watershed-based restoration efforts developed to \\ maximize the ecological recovery of acid mine drainage (AMD) impaired streams. We sampled \\ water chemistry, physical habitat, benthic macroinvertebrate and fish community structure in 3 \\ stream types: AMD (14 streams), AMD-treated (13 streams), and unimpaired reference (4 \\ streams). Treatment technology implemented on impaired streams included in-stream active \\ treatment dosers, limestone sand applications, and an at-source passive treatment system. \\ Assessment sites were strategically selected based on treatment locations, and we evaluated \\ conditions pre-treatment and 3 years post-treatment. Water chemistry varied widely. Sites \\ impaired by AMD improved in water quality with AMD treatment. For example, dissolved \\ metals and acidity declined but treatment waters remained elevated in sulfate and conductivity. \\ Likewise, biotic conditions varied widely and sites impaired by AMD improved in bio-condition \\ scores with AMD treatment. For example, EPT genera increased but were still low. In addition, \\ we found fish at 9 sites that previously had none. Community-level analyses indicated improved \\ but altered assemblage of taxa at treated sites compared to untreated sites. Overall, general \\ improvements in water quality and bio-condition at the stream-scale were associated with \\ improvements in a measure of ecological value at the watershed scale. Our results suggest that \\ unique communities driven by the new water chemistry signature are being formed. Only 3 years \\ have passed since project completion and communities that reflect true reference may require
}


more time. This general framework for adaptive watershed management developed for mined watersheds can also be applied to other anthropogenic impacted watersheds in this region. Applying an experimental approach towards restoration project assessments can facilitate restorationists and project managers to understand what types of treatment accomplish their goals.

Key words: Acid mine drainage (AMD), adaptive watershed management, biological communities, field experiment, water chemistry, and watershed restoration. 


\section{Introduction}

Acid mine drainage (AMD) from abandoned mine lands (AMLs) has remained a wellposed problem associated with mining. This acidification of surface and groundwater is a persistent environmental issue with global dimensions (Bott et al. 2012). The effects of AMD are well documented globally in countries such as the United States (US) (Freund and Petty 2007), Australia (Lei et al. 2010), Bolivia (Strosnider et al. 2011), South Africa (McCarthy 2011), Thailand (Changul et al. 2010), India (Pandey et al. 2007), and Spain (Sarmiento et al. 2011). AMD forms when sulfide minerals are exposed to oxidizing conditions from mining activities or other land disturbances (Skousen 1995). In the presence of water and oxygen, sulfide minerals oxidize releasing metals, sulfate, and acidity. When these acidic drainages enter streams from AMLs they pose a major potential source of pollution to aquatic ecosystems (Brenner et al. 1995). In central Appalachia, the effects of coal mining on flowing waters may be one of the most crucial environmental issues in the US (Petty et al. 2010). In this region of the world, coal has been mined for nearly 200 years (Merovich et al. 2007), and as a result, more than 17,000 $\mathrm{km}$ of streams in the Mid-Atlantic Highlands are impacted by AMD (USEPA 2000). The water chemistry signature associated with AMD in north central Appalachia consists of low $\mathrm{pH}$, high conductivity, and high total dissolved solids in the form of sulfates and metals (Merovich et al. 2007). These acidic drainages are crippling to the ecological and economic benefits of streams throughout West Virginia (WV) and the entire Appalachian region (Petty et al. 2008).

A considerable amount of research and development on the remediation of AMD impacted watersheds has been done to alleviate the stress of mining on aquatic ecosystems in Appalachia (Freund and Petty 2007, Merovich et al. 2007, Petty et al. 2008). In 2006, the US Congress reauthorized the Abandoned Mine Land (AML) Program to address the widespread 
impairment of streams from AMD throughout WV and the entire central Appalachian region (Petty et al. 2008). This expanded AML program experienced a substantial increase in allocations allowing the WV Department of Environmental Protection (WVDEP) Office of Abandoned Mine Land and Reclamation the ability to establish a goal of maximizing the statewide recovery of fisheries (Petty et al. 2008); however, due to the extensive impacts of prelaw mining, and the immense number of acid-impacted streams in the central Appalachian region, the problem of reclaiming all sources of impairment still remains (Petty and Thorne 2005, Petty et al. 2008). As a result, the ability to identify restoration priorities within a targeted watershed is needed (Merovich et al. 2013). In response, an adaptive watershed management program was deployed for application to AML reclamation in mined WV watersheds (Petty et al. 2008). The framework of this program is cyclical and its adaptive nature implies that every management action should be viewed as an experiment to be monitored (Cushing and Allan 2001, Petty et al. 2008). This adaptive watershed management program brings Cushing and Allan's (2001) general protocol to protect and restore our rivers full circle. This management program is essentially a product of their "blueprint", with foundations based in current science and management to effectively restore AMD-impacted watersheds.

In 2007, the West Virginia Water Research Institute (WVWRI) proposed a strategic watershed-based restoration plan, following adaptive watershed management principles, for the Abram Creek watershed to the WVDEP Office of Abandoned Mine Land and Reclamation. In 2010 the project was completed. The final step of the adaptive watershed management cycle is the assessment of watershed scale improvements resulting from the implementation of remediation actions. Palmer et al. (2003) believe that the science of riverine restoration has suffered from lack of evaluation. Without long-term monitoring of restoration efforts from particular management experiments, valuable knowledge is lost (Cushing and Allan 2001). The 
importance of post-restoration monitoring and evaluation as the final step in the adaptive watershed management program cannot be overstated. It is with this final step that the process begins anew, and remediation efforts continue to evolve improving overall water quality and quantity, biodiversity, and ecological processes which watershed-based restoration efforts aim to achieve.

The overriding objective of our study was to use an experimental approach to evaluate the effectiveness of watershed-based restoration efforts developed to maximize the ecological recovery of AMD impaired streams. The specific objectives were to: 1) quantify the response of water chemistry, benthic macroinvertebrates, and fishes to AMD treatment 3 years after restoration efforts were implemented; and 2) quantify the putative benefits of restoration efforts at the watershed scale.

\section{Methods}

Study Area

Abram Creek is a $115-\mathrm{km}^{2}$ watershed (North Branch/Potomac River basin) located in West Virginia’s eastern panhandle in Grant and Mineral Counties (lat 39¹8'44.8’, long $\left.79^{\circ} 12^{\prime} 41.2^{\prime \prime}\right)$. The mainstem is $31.5 \mathrm{~km}$ long, and joins the North Branch of the Potomac River near Kitzmiller, Maryland. Land cover is dominated by forest (66\%) and agriculture (25\%). The geology of the watershed consists predominantly of shale and sandstone. The watershed contains 23 subwatersheds, the largest of which are Emory Creek, Glade Run, Johnnycake Run, and Laurel Run (Figure 1). Impairments throughout the watershed are primarily due to AMD from AMLs (WVWRI 2007). WVDEP's Division of Water and Waste Management identified 27 abandoned mine sources (discharges, seeps, portals, culverts, refuse piles, diversion ditches, and 
ponds) throughout the study area (WVWRI 2007). There are 8 NPDES permits in the watershed for metal effluents related to mining (WVWRI 2007).

The AMD-treatment technology implemented in the Abram Creek watershed includes 3 in-stream active treatment dosers at the Abram Creek headwaters, Little Creek, and an unnamed tributary (Morgan 25 site) at river kilometer 6.2; 2 limestone sand dump sites at Laurel Run and Emory Creek, and 1 passive treatment system at Glade Run (Figure 1, Table 1). In-stream active treatment dosers were installed adjacent to the impacted tributaries. This treatment technology diverts water to a water wheel that drives an auger and powers a doser, which adds calcium oxide in proportion needed to neutralize in-stream acidity. The treated water returns to the stream where precipitation reactions occur. Limestone sand application is performed by dumping sand along the stream bank where gravity and stream water gradually wash the sand downstream. The passive treatment system installed incorporated kiln dust, a waste product of the limestone industry, into the stream bed and bank where an abandoned mine portal discharges AMD.

We studied a total of 18 sites within the study area. Sites were strategically selected based on treatment locations to evaluate the putative benefits of treatment (Figure 1). In 2008, before treatment, 14 sites were sampled. These same 14 sites were sampled again in 2013, after treatment. An additional 4 sites were sampled in 2013, after treatment, to characterize supplementary reference and untreated AMD streams within the study area.

Streams were classified into 3 a priori types: 1) streams impaired by AMD (14 streams); 2) streams treated for AMD impairment (13 streams); and 3) unimpaired reference streams (4 streams). AMD (A) streams were listed on the 2004 303d list for water quality and/or biological impairment (WVWRI 2007). Treated (T) streams received AMD-treatment or were downstream of treatment. Reference (R) streams were naturally circumneutral. Circumneutral streams within 
the study area represent the "best available conditions" in the watershed and provide the only reasonable reference condition against which to assess watershed-based restoration plans (Campbell 2000, McClurg et al. 2007).

\section{Field Sampling}

\section{Physicochemical}

Water chemistry was monitored in May of 2008 and 2013 at each assessment site. A 1-L unfiltered grab sample and $500-\mathrm{mL}$ filtered sample $(0.45 \mu \mathrm{m}$ pore sized membrane discs $)$ were collected. Filtered samples were treated immediately with nitric acid to prevent metals from precipitating. All samples were kept on ice after collection and stored at $4{ }^{\circ} \mathrm{C}$ until analyses were completed. Samples were analyzed at the National Research Center for Coal and Energy at West Virginia University for alkalinity (mg/L $\mathrm{CaCO}_{3}$ equivalents), acidity (mg/ $\mathrm{L} \mathrm{CaCO}_{3}$ equivalents), sulfate $\left(\mathrm{mg} / \mathrm{L} \mathrm{SO}_{4}\right)$, total dissolved aluminum, barium, copper, chloride, cobalt, chromium, cadmium, calcium, sodium, nickel, selenium, zinc, iron, magnesium, and manganese concentrations $(\mathrm{mg} / \mathrm{L})$. In addition, temperature $\left({ }^{\circ} \mathrm{C}\right), \mathrm{pH}$, specific conductance $(\mu \mathrm{S} / \mathrm{cm})$, dissolved oxygen $(\mathrm{mg} / \mathrm{L})$, and total dissolved solids $(\mathrm{g} / \mathrm{L})$ were measured in situ using a YSI 650 with a $600 \mathrm{XL}$ sonde (Yellow Springs, OH). Stream discharge was measured using the areavelocity technique with a Marsh-McBirney Flo-Mate 2000 flow meter (Marsh-McBirney, Frederick, MD). Physical habitat condition was evaluated with rapid visual habitat assessment (RVHA) techniques for each site in the late summer of 2008 and 2013 following US Environmental Protection Agency (USEPA) protocols (Barbour et al. 1999). Parameters were measured by the same observer within years to maximize repeatability and reduce errors in the data (Roper and Scharnecchia 1995, Freund and Petty 2007). 


\section{Benthic Macroinvertebrates and Fishes}

Biological condition at each site was monitored by collecting benthic macroinvertebrate and fish assemblage data. Benthic macroinvertebrates were sampled at each assessment site in May of 2008 and 2013 following rapid bioassessment protocols for wadeable rivers (Barbour et al. 1999). At each site 4 kick samples were obtained using a rectangular style kick-net (net dimensions 355 x $508 \mathrm{~mm}$ with $500 \mu \mathrm{m}$ netting) from widely separated riffle habitat to sample a total of $1.0 \mathrm{~m}^{2}$. All 4 samples were filtered through a $250 \mu \mathrm{m}$ sieve, combined into a single composite sample, and preserved in $95 \%$ ethanol. Subsampling followed a modified version of the USEPA's Rapid Bioassessment Protocol. 200 macroinvertebrates were selected by picking macroinvertebrates from randomly selected grid cells (WVDEP 2013). All macroinvertebrates were identified to genus or the lowest possible taxonomic level using Peckarsky et al. (1990) and Merritt and Cummins (2008). Fish assemblage data was monitored in the late summer of 2008 and 2013. 1 to 3 backpack electrofishing units (Smith Root models 12-B, 15-D, and/or LR-24) were used depending on the size of the stream (Freund and Petty 2007). Assessment site reaches were 40 times the mean stream width or a minimum of $150 \mathrm{~m}$ and a maximum of $300 \mathrm{~m}$ in length. All individuals captured were identified to species and returned to the stream after completion of the assessment site.

\section{Statistical Analyses}

\section{Physicochemical}

To quantify the response of water chemistry to AMD treatment, we used a combination of multivariate statistics and ordination procedures. Prior to analyses, all water chemistry variables except $\mathrm{pH}$ were log transformed to better approximate the assumption associated with 
parametric statistics. Alkalinity was normalized after adding $1 \mathrm{mg} / \mathrm{L} \mathrm{CaCO}_{3}$ equivalents to its value, and total acidity was removed from the analysis due to its strong dependence on other chemical elements (Merovich et al. 2007). Cadmium was not included in the analysis because all concentrations returned by the lab were below the detection limit. First, as a visual aid, we used principal component analysis (PCA) to analyze the water chemistry data before and after treatment. PCA reduces the dimensionality of a large multivariate dataset to a minimum number of important dimensions that explain covariance patterns. Principal components (PCs) with eigenvalues $>1.0$ were considered significant (McGarigal et al. 2000). Water chemistry parameters were considered strongly correlated to a PC if their factor loadings had an absolute value >0.5 (McGarigal et al. 2000). Separation of water samples (e.g., AMD type) in ordination space was used to interpret the degree of difference in water quality (i.e., chemical make-up) relative to other sample types (e.g., treated type). To provide statistical support for trends detected in PCA, we used multivariate analysis of variance (MANOVA) to determine if a priori stream types had statistically different water chemistry signatures. Analysis of variance (ANOVA) and Tukeys post-test were used to determine which specific water chemistry parameters were statistically different among stream types.

To further examine the chemical response to treatment, we calculated acid loads and the net acidity at the mouth of the watershed and major tributaries pre- and post-treatment. Acid and alkalinity loads were calculated as follows: Acid load = Flow in gallons per minute $(\mathrm{gpm}) \mathrm{x}$ Acidity (mg/L) x 0.0022 (conversion factor from mg/L/gpm to tons/yr). Flows for each of the major tributaries receiving AMD-treatment were calculated by using the flow with drainage area ratio method (Emerson et al. 2005). To calculate drainage area we used a hydrologic model in ArcMap Version 10.1 (Environmental Systems Research Institute, Redlands, CA, U.S.A.) to find 
the total flow accumulation values for each major tributary receiving AMD-treatment. Net acidity was calculated by subtracting alkalinity from calculated acidity. Lastly, we used MANOVA to determine if rapid visual habitat parameters differed between a priori stream types.

\section{Benthic Macroinvertebrates and Fishes}

To investigate the response of fish and macroinvertebrate communities to watershedbased restoration plans, we used a combination of multivariate statistics and ordination procedures. First, to visualize shifts in community composition among stream types we calculated the Bray-Curtis dissimilarity among sites for each of fish species and benthic macroinvertebrate genus abundance data. Then, using nonmetric multidimensional scaling (NMDS) we mapped sites in k-dimensional space based on a list of attributes (i.e., taxonomic composition; Bray-Curtis distance metric) while minimizing stress in the plot. NMDS is a visual synthesis, data reduction technique. In NMDS, sample sites that map close to each other are more similar in taxonomic composition than sites that map further apart. To interpret the gradient structure in the NMDS solutions, we labeled samples (sites) in ordination space with a priori stream types and added to the ordination the weighted mean positions of selected taxa. We also correlated biological metrics and water chemistry parameters to the ordinations. Correlations were considered statistically significant when $\mathrm{p}<0.05$. Next, applying analysis of variance using distance matrices (ADONIS; i.e., non-parametric multivariate analysis of variance) we determined whether a difference existed among communities from different stream types. In addition, the West Virginia Stream Condition Index (WVSCI), a family-level index of biotic integrity (IBI), and the Genus Level Index of Most Probable Stream Status (GLIMPSS), a genuslevel IBI, was used to quantify ecological integrity at each sample site (Gerritsen et al. 2000, Pond et al. 2008). ANOVA and Tukeys post-test were used to determine which specific benthic 
macroinvertebrate and fish metrics were statistically different among stream types. Paired t-tests were used to compare macroinvertebrate IBIs before and after treatment. All statistical analyses were conducted in the R statistical environment Version 3.0.2 (R Development Core Team 2013). NMDS and ADONIS were performed with the package vegan (Oksanen et al. 2013).

\section{Ecological Currency}

To calculate a measure of ecological currency to quantify the putative benefits of restoration efforts throughout the stream continuum we calculated ecological units (EUs). EUs are weighted values, in units of stream length, which represent the availability of ecologically functioning stream habitat (Petty and Throne 2005, Merovich and Petty 2007). These units have elasticity and can be customized for individual stream reaches. First, we assigned each of our observed pre- and post-treatment WVSCI scores to their most appropriate segment-level watershed (Strager et al. 2009). Next, we linearly interpolated WVSCI scores between segmentlevel watersheds bounded by observed scores. This was necessary to assign WVSCI scores to un-sampled segment-level watersheds throughout the stream continuum. WVSCI scores were then standardized to 1.0 by dividing by the highest score observed pre- and post-treatment throughout the watershed. Each standardized score was then multiplied by its respective stream segment length to attain EUs in stream kilometers. We then standardized each segment-level watershed EU to the total stream kilometers sampled for the pre- and post-treatment time frames. This calculation provides a percentage of the total EUs existing in a segment-level watershed. A segment-level watershed with $100 \%$ EUs present implies that the stream is functioning at $100 \%$ of that expected for streams in the region. Conversely, $0 \%$ EUs present implies a highly degraded stream failing to function as ecological habitat. This ecological currency allows us to quantify and compare the ecological condition pre- and post-treatment to determine if restoration 
efforts accrued ecological benefits at individual segment-level watersheds and throughout the entire dendritic ecological network in a cumulative fashion. Finally, a two-sample KolmogorovSmirnov test was used to determine if a statistical difference existed between the cumulative distributions curves of pre-treatment EUs versus post-treatment EUs when accumulated from the headwaters to the mouth.

\section{Results}

\section{Physicochemcial}

We observed high variability in water chemistry throughout the watershed. PCA revealed 4 important dimensions of variation (eigenvalues > 1.0). Only PC 1 and PC 2 were interpreted, because they were statistically different among stream types (Table 2). Combined, PC 1 and PC 2 explained $69 \%$ of the variance observed in water chemistry. PC 1 is interpreted as a pollution gradient explaining $46 \%$ of the variance. PC 1 is strongly correlated with aluminum, barium, copper, cobalt, chromium, nickel, zinc, sulfate, iron, magnesium, and manganese in the positive direction (Figure 2). Alkalinity and $\mathrm{pH}$ are correlated negatively with PC 1 (Figure 2). PC 2 is interpreted as a hardness gradient explaining $23 \%$ of the variance in water chemistry data. PC 2 is strongly correlated with conductivity, calcium, magnesium, sodium, and sulfate in the positive direction (Figure 2). Copper and chromium are correlated negatively with PC 2 (Figure 2). In terms of water chemistry, MANOVA shows a statistical difference between stream types (Fvalue $=16.923 ; \mathrm{df}=2,29 ; \mathrm{p}$-value $\left.=5.6 \times 10^{-11}\right)$. ANOVA $(\mathrm{p}<0.05)$ shows nickel, zinc, and manganese is statistically different among all stream types (Table 2). Aluminum, barium, copper, cobalt, chromium, and iron concentrations are statistically higher in AMD stream types compared to treated and reference stream types, while $\mathrm{pH}$ and alkalinity concentrations are statistically higher in treated and reference stream types compared to AMD stream types (Table 
2). Conductivity, sulfates, calcium, and magnesium concentrations are statistically higher in AMD and treated stream types compared to reference stream types, and chloride, sodium, and selenium concentrations are all statistically equivalent among stream types (Table 2).

Acid loads and net acidity calculated at the mouth of the watershed and all major tributaries receiving AMD-treatment declined, except at Laurel Run. Specifically, the acid load at the mouth of Abram Creek was reduced from 330 tons/yr to 34 tons/yr. Emory Creek was observed to have the greatest reduction in net acidity compared to other treated tributaries at -220 tons/yr. Laurel Run was observed to gain approximately 16 tons/yr of acidity (Table 3). MANOVA revealed that there is no statistical difference in rapid visual habitat components among stream types $(\mathrm{F}$-value $=1.0648 ; \mathrm{df}=2,30 ; \mathrm{p}$-value $=0.4161)$.

\section{Benthic Macroinvertebrates and Fishes}

Biological conditions varied widely throughout the watershed. NMDS ordinations indicate that communities are responding to water chemistry improvements (Figure 3 and 4). The macroinvertebrate metric \% Ephemeroptera was strongly correlated (p-value $<0.05)$ in the direction of treated sites (Figure 3). When further examining the assemblage data we found that the taxa predominantly correlated to improvements were from the family Baetidae, specifically the genera Plauditus and Acentrella. The global ADONIS revealed differences in both benthic macroinvertebrate $\left(\mathrm{p}\right.$-value $=0.004, \mathrm{R}^{2}$ value $\left.=0.14\right)$ and fish $\left(\mathrm{p}\right.$-value $=0.001, \mathrm{R}^{2}$ value $\left.=0.38\right)$ communities from different stream types. ADONIS pairwise comparisons show that AMD stream type benthic macroinvertebrate communities are statistically different from treated stream type $\left(p\right.$-value $=0.033, R^{2}$ value $\left.=0.09\right)$ and reference stream type $\left(p\right.$-value $=0.013, R^{2}$ value $=$ $0.15)$ communities. There was a marginal difference among treated stream type and reference stream type benthic macroinvertebrate communities $\left(p\right.$-value $=0.07, R^{2}$ value $\left.=0.11\right)$. ADONIS 
pairwise comparisons for fish communities revealed that all stream type communities are statistically different from one another.

Paired t-tests showed that benthic macroinvertebrate IBI values increased statistically after treatment compared to before, with the family level WVSCI ( $\mathrm{p}$-value $=0.0001, \mathrm{df}=12$ ), and with the genus level GLIMPSS ( $\mathrm{p}$-value $=0.0002$, $\mathrm{df}=12)$. ANOVA $(\mathrm{p}<0.05)$ shows that GLIMPSS and the EPT genus richness metric are statistically different among all stream types (Table 4). The \% Chironomid metric is statistically higher in AMD stream types compared to treated and reference stream types, while \% EPT families and WVSCI are statistically higher in treated and reference stream types compared to AMD stream types (Table 4).

Fish were found at 9 stream segments that previously had none, 2 of which had Salvelinus fontinalis (brook trout) and 1 of which had Micropterus dolomieu (smallmouth bass). Brook trout were found in an abundance of 11 and 9 at Emory Creek and Glade Run, respectively. Smallmouth bass were found in an abundance of 26 at Abram Creek above Emory. All sites that previously lacked fish had Semotilus atromaculatus (creek chub). ANOVA (p < 0.05) shows that fish species richness is statistically higher in treated and reference stream types compared to AMD stream types; while the proportion of macro-omnivores and gravel spawning species is statistically different among all stream types, and the proportion of invertivorepiscivore individuals is statistically higher in treated stream types compared to AMD and reference stream types (Table 4).

\section{Ecological Units}

In $2008,68.5 \%$ of the total possible EUs were present in the watershed. In 2013, 3 years after AMD-treatment, 83.4\% of EUs were present (Figure 5). EUs at the mouth of the watershed 
increased by $\sim 15 \%$ after treatment compared to before. All segment-level watersheds receiving treatment with the exception of Glade Run experienced an increase in EUs (Table 5, Figure 6). The two-sample Kolmogorov-Smirnov test suggests that EUs did not accumulate along the river at a statistically higher rate after restoration compared to before restoration ( $\mathrm{p}$-value $=0.5026$ ). However, noticeable ecological lifts were observed after restoration compared to before. For example, initial cumulative ecological benefits were observed downstream from the in-stream active treatment dosers, and the most prominent cumulative ecological lift was observed on the Abram Creek mainstem between river kilometers 26.5 and 28.3, above Emory Creek (Figure 5). At this site in 2008, before treatment, no fish were present. In 2013, after treatment, high abundances of creek chub, Rhinichthys atratulus (eastern blacknose dace), and smallmouth bass were observed.

\section{Discussion}

In this study we were able to complete the adaptive watershed management cycle for the Abram Creek watershed restoration project. By using an experimental approach, we hoped to gain a realistic view of the benefits and shortcomings of watershed-based restoration efforts developed to recover an intensively mined Appalachian watershed. Our findings bring up several significant points. First, water chemistry greatly improved at the watershed scale. Second, biota improved noticeably, but have not returned to reference conditions; and third, the restoration treatment plan documented a reconnection of the watershed.

\section{Restoration Benefits}

The watershed-based restoration plan chosen for application to the Abram Creek watershed reduced the acid loads and net acidity calculated at the mouth and all major tributaries 
receiving AMD-treatment with the exception of Laurel Run. Our finding of improved water quality as a result of AMD-treatment is consistent with numerous studies conducted in this region (TU 2011, Simon et al. 2012, Carlson 2013). We characterized the overall chemical response to AMD-treatment as a transition from metal laden acidic waters to hard waters with elevated sulfate concentrations and conductivity. Although this new water chemistry signature is a departure from reference conditions, biological community assemblages are responding to these chemical improvements.

Our results suggest that benthic macroinvertebrate communities in treated stream types are improving noticeably, and appear to be shifting towards reference stream types in the Abram Creek drainage. However, a deviation from reference community composition exists. Several studies have observed little to no recovery and delayed recovery in benthic macroinvertebrate communities following restoration (Bradley and Ormerod 2002, LeFevre and Sharpe 2002, Simmons et al. 2005, Gunn et al. 2010, Louhi et al. 2011). These results are often attributed to physical factors such as drought and distance to treatment (LeFevre and Sharpe 2002, Gunn et al. 2010); chemical factors such as varying levels of AMD inputs and treatment, episodic acidification, and scarcity of organic matter input (Bradley and Ormerod 2002, Simmons et al. 2005, Gunn et al. 2010); historic factors such as legacy logging, mining, and channelization (Louhi et al. 2011); and biological factors such as the lack of local (alpha) or regional (beta) diversity, as well as the order of arrival of colonists (Gunn et al. 2010, Louhi et al. 2011). We recognize that all of these factors play a role in the recovery of biological community structure, and acknowledge that full ecosystem recovery to reference conditions may not be realistic; however, only 3 years have passed since project completion and communities that reflect true reference may require more time to recolonize. One explanation of the improved, but altered 
assemblage of taxa at treated sites could be that treated stream types are being colonized by pioneer invertebrate assemblages. Winking et al. (2014) found that benthic macroinvertebrate communities in connected, restored sites need 9 to 19 years to reach a mature community. In terms of community succession, a restored site may be defined as mature when the taxonomic composition resembles that of a reference site (Winking et al. 2014).

The genera predominantly responsible for improvements in benthic macroinvertebrate communities at treated sites were from the family Baetidae, specifically the genera Plauditus and Acentrella. These genera are found in lotic habitat, commonly in erosional (gravel-sand) and depositional (sand) substrate; they are primarily swimmers and secondary clingers; and belong to the functional feeding group gatherer/collector (Barbour et al. 1999, Merritt and Cummins 2008). Both Plauditus sp. and Acentrella sp. have a tolerance value of 4 in the Mid-Atlantic region (Barbour et al. 1999, Merritt and Cummins 2008). This tolerance value is on a 0 to 10 scale -0 representing an extremely sensitive taxa and 10 representing tolerant taxa (Barbour et al. 1999). Vieira et al. (2004) characterized Baetid mayflies as being strong larval dispersers, and found a Baetid species to rapidly recolonize and dominate benthic communities during early postdisturbance years. Additional studies examining successional sequences have found the family Baetidae to be early colonists after catastrophic watershed-scale disturbances (Flory and Milner 2000, Zuellig et al. 2002). Strong dispersal capability coupled with low habitat specificity defines these taxa as pioneer species (sensu Gore 1982). It is evident that benthic macroinvertebrate assemblages are recovering, and unique communities driven by the new water chemistry signature are being formed as a result of AMD treatment.

Fish assemblages are also recovering. However, similar to benthic macroinvertebrate assemblages, fish assemblages have not returned to reference conditions. Despite differences in 
community structure among stream types, we found fish present at 9 assessment sites which previously had none. All sites that previously lacked fish had creek chub. Creek chub are common in small medium- to high-gradient streams and tolerant of many pollutants (McMahon 1982, Leonard and Orth 1986). This insectivorous cyprinid is a generalist feeder (Karr 1981), and only a minor part of healthy fish communities except in small headwater streams (Leonard and Orth 1986). This was the only species of fish found in upper Abram Creek; however, further downstream from the 3 in-stream active treatment dosers, we observed brook trout, smallmouth bass, and eastern blacknose dace. Brook trout were found at 2 of the sites which previously had none. In 2007, before project completion, Johnnycake Run and its tributary Wycroff Run were the only streams in the watershed classified as trout waters (WVWRI 2007). This movement of a sensitive species into stream segments which previously lacked fish suggests that previously isolated streams were reconnected with the dendritic ecological network both within and outside of the treated watershed. Petty et al. (2005) found that nearly $80 \%$ of all spawning by brook trout occurred in stream segments with a drainage area less than $3 \mathrm{~km}^{2}$, and successful reproduction was observed only in stream segments where alkalinity exceeded $7 \mathrm{mg} / \mathrm{L} \mathrm{CaCO}_{3}$ equivalents. Our findings of brook trout at the 2 treated stream segments are consistent with the physical and chemical criteria outlined by Petty et al. (2005) for successful brook trout recruitment.

In a complete stream ecosystem assessment of restoration efforts developed to remediate the effects of acid-precipitation, McClurg et al. (2007) found that limestone treatment did not fully recover dissolved aluminum concentrations, macroinvertebrate taxa richness, and total fish biomass to reference conditions in acid impacted watersheds of the Allegheny Plateau. They accredit these restoration shortcomings to the possibility that treated streams remain isolated in a 
network of acidic watersheds. McClurg et al. (2007) proposed that stream restoration plans should focus on restoring stream ecosystems as connected networks rather than isolated reaches. We acknowledged this revised stream restoration strategy and found that restoration plans aimed at the watershed scale reconnected the lower Abram Creek watershed to the North Branch of the Potomac River. This concept of restoring connectivity of stream reaches is well documented in the literature (Freund and Petty 2007, Jansson et al. 2007, Lake et al. 2007), and is vital for the recovery of biological communities. In theory, restoration efforts aimed at increasing watershed connectivity should allow for the full movement and recolonization potential of both fish and aquatic invertebrates (McClurg et al. 2007). To promote the recovery of interconnected stream networks, restoration programs must shift restoration efforts from the local scale to the watershed scale.

\section{Restoration Shortcomings}

In this field experiment and ecological evaluation of holistic watershed-based restoration efforts, we did not observe full ecosystem recovery of all water chemistry parameters assessed and biological communities to reference conditions. In particular, the addition of alkaline material did not decrease sulfate concentrations or specific conductivity to levels comparable to reference conditions. Pond et al. (2008) found biological impairment when conductivity was greater than $500 \mu \mathrm{S} / \mathrm{cm}$. A more recent study observed biological impairment when conductivity reached $250 \mu \mathrm{S} / \mathrm{cm}$ (Merriam et al. 2011). In addition to high conductance, sulfate concentrations were observed to remain elevated. Freund and Petty (2007) observed a negative correlation between sulfate concentration and biotic indices; however, this correlation was paired with a suite of dissolved metal concentrations making it extremely difficult to determine which chemical parameters actually cause biological impairment. These results suggest that although 
metal concentrations have decreased and $\mathrm{pH}$ and alkalinity have increased, high conductance due to increases in water hardness (i.e. calcium and magnesium concentrations), and elevated sulfate concentrations may restrict communities from reflecting true reference in this region.

Another restoration shortcoming we observed was an increase in net acidity at Laurel Run after treatment. Laurel Run was also the only site receiving AMD-treatment not to have fish despite a minimal increase in benthic macroinvertebrate IBI scores. One explanation could be the current mining activity occurring in the Laurel Run drainage. A mining company holds a refuse disposal permit in the drainage, and AMD seeps above the stream are affecting the limestone sand treatment (J. Baczuk 2014, WVDEP, personal communication). We also observed a decrease in EUs at Glade Run where the passive treatment system was installed. Here we observed a small decrease in benthic macroinvertebrate IBI scores 3 years after initial treatment. In a recent study by Coberly and Rice (2013), passive treatment systems were assessed by the WV AML program for their overall success. They observed an initial improvement in water chemistry parameters at a majority of systems initially after installation, but found that sites frequently returned to pre-treatment conditions after only a few years.

\section{Implications for Watershed-based Restoration Programs}

Historically, most restoration projects were small scale, being carried out on stream segments less than $1 \mathrm{~km}$ in length (Bernhardt et al. 2005). These restoration efforts were focused on improving environmental conditions at the local, segment-level, scale. Typically, projects that are evaluated tend to be measured by diversity-based bioassessment techniques used to determine the success or failure of projects (Brown et al. 2011). Therefore, even though stream restoration may be an effective means in rebuilding a local environment, it may remain disconnected from the populations and communities it was meant to support (Brown et al. 2011). 
Restoration projects that fail to meet the expected results evaluated by diversity-based bioassessment techniques may not be a failure in terms of structure and function, but a product of depressed regional factors such as dispersal, large-scale disturbance, and depletion of the regional species pool (Brown et al. 2011). These segment-level restoration projects commonly fell victim to the "field of dreams" myth (Hilderbrand et al. 2005). This assumption that "if you build it they will come" focuses entirely on the local scale ignoring processes occurring in the broader context, such as the connectivity between metacommunities (Merovich et al. 2013). If barriers to dispersal exist at the regional scale, colonizers will be unable to access the newly acquired habitat, which if assessed based on biological community composition may be deemed a restoration failure. Metacommunity theory suggests that "if you build it, they may not come" (Brown et al. 2011). By sampling populations and communities within a watershed, the regional species pool can be captured, and integrated into the future restorability of the program. Gaining insight on the regional species pool, and integrating both local and regional information on the surrounding landscape within the metacommunity framework should improve the likelihood of success for river restoration projects (Brown et al. 2011, Merovich et al. 2013).

Not only is there a lack of pre- and post-restoration monitoring, but a lack of what constitutes restoration success (Bernhardt et al. 2005, Palmer et al. 2005, McClurg et al. 2007). Restoration projects evaluated by diversity-based bioassessment techniques should be founded on reconnecting the regional species pool to locally improved habitat suitable for communities to persist. Merovich et al. (2013) propose a framework for setting restoration and protection priorities following a house-neighborhood-community approach. This analogy views houses (stream segments) embedded within neighborhoods (HUC-12 watersheds) embedded within communities (HUC-10 watersheds). Within this analogy, restoration priorities are aimed at 
impaired neighborhoods in good communities and impaired houses in good neighborhoods (Merovich et al. 2013). This multiscale approach ensures that restoration efforts build on existing high-quality conditions (Merovich et al. 2013). By reconnecting a desired regional species pool to improved local habitat patches the science of watershed restoration ecology should progress in a more effective direction both ecologically and economically.

Bernhardt et al. (2005) state that strategic pre- and post-restoration assessments with standardized methods could enable restorationists and project managers to understand what types of treatment are accomplishing their goals. We took a strategic, experimental approach to provide baseline remediation data for the assessment of progress towards implementing the master plan of the Abram Creek watershed restoration program. The use of EUs in our analysis allowed us to quantify the response of ecological conditions to treatment at both the local and regional scale. By assigning an ecological currency to individual segment-level watersheds we were able to determine the extent of treatment technologies on the ecological recovery of specific drainages, as well as the cumulative benefits of treatment to the entire dendritic ecological network. This approach proved useful in identifying which types of treatment are achieving desired ecological results. Similar procedures can be used to enable restorationists and watershed managers to apply a cost-benefit approach to choose the best restoration alternative available to invest restoration dollars into (Petty et al. 2008).

In conclusion, we were able to complete the adaptive watershed management cycle for the Abram Creek watershed restoration plan. This post-restoration assessment documented a reconnection of the watershed, and significantly improved ecological conditions and fisheries in Abram Creek. These improvements were notably observed downstream of in-stream active treatment dosers and limestone sand dump sites throughout the watershed, with the exception of 
Laurel Run which may have been compromised due to ongoing mining activity. Only 3 years have passed since project completion and communities that reflect true reference may require more time. A limitation to our study was that sampling only occurred once before and after treatment. This snapshot of ecological conditions throughout the watershed may not identify trends or variability found in long-term datasets. However, we believe that our sampling protocol was sufficient to characterize the chemical, biological, and physical integrity of the Abram Creek watershed pre- and post-treatment at both the local and regional scale. Benthic macroinvertebrates are good indicators of local conditions (Freund and Petty 2007). Their sedentary nature allows for the effective determination of the spatial extent of environmental stress, and their long life cycles allow for temporal changes in community structure to be examined (Rosenberg et al. 2008). Fish are good indicators of regional conditions due to their high mobility and long lives (Freund and Petty 2007). Biological monitoring of both fish and aquatic invertebrate communities for diagnosing historic and chronic stressors, the effects of aquatic habitat fragmentation, and stressors that have local and regional impacts (Freund and Petty 2007) can be determined at the watershed-scale. We fully expect this general framework for adaptive watershed management developed for mined watersheds to be able to be applied to other anthropogenic impacted watersheds in this region. We believe that by adopting a metacommunity approach to guide the practice of stream restoration ecology successful recolonization of biological organisms is attainable. Continued long-term monitoring of the Abram Creek watershed is needed to evaluate restoration progress valuable toward advancing the science of watershed restoration ecology, contributing to the future health of our streams and rivers. 


\section{Implications for Practice}

- Applying an experimental framework towards restoration project assessments can facilitate restorationists and project managers to understand what types of treatment accomplish their goals.

- Adaptive watershed management developed for mined watersheds can also be applied to other anthropogenic impacted watersheds in this region.

- Adopting a metacommunity approach to guide the practice of stream restoration ecology should produce successful restoration results. 


\section{Acknowledgements}

We would like to thank Donna Hartman, Eric Miller, Eric Merriam, Brock Huntsman, and Alison Anderson for their help in field sampling and laboratory analysis. We would also like to thank Jim Baczuk from WVDEP Office of Abandoned Mine Lands and Reclamation for sharing his expertise and overlooking the operation and maintenance for the Abram Creek watershed restoration project. This work was funded, in part, by the Appalachian Research Initiative for Environmental Science, the West Virginia Water Research Institute, and West Virginia University, Division of Forestry and Natural Resources. 


\section{Literature Cited}

Barbour M. T., J. Gerritsen, B. D. Snyder, and J. B. Stribling.1999. Rapid bioassessment protocols for use in streams and wadeable rivers: periphyton, benthic macroinvertebrates, and fish. U.S. Environmental Protection Agency, Office of Water, Washington, DC.

Bernhardt E. S., J. Follstad-Shah, D. Galat, S. Gloss, P. Goodwin, D. Hart, B. Hassett, R. Jenkinson, S. Katz, G. M. Kondolf, P. S. Lake, M. A. Palmer, R. Lave, J. L. Meyer, T. K. O'Donnell, L. Pagano, B. Powell, E. Sudduth, J. D. Allan, G. Alexander, K. Barnas, S. Brooks, J. Carr, S. Clayton, and C. Dahm. 2005. Synthesizing U.S. river restoration efforts. Science 308(5722):636-637.

Bott T. L., J. K. Jackson, M. E. Mctammany, J. D. Newbold, S. T. Rier, B. W. Sweeney, and J. M. Battle. 2012. Abandoned coal mine drainage and its remediation: Impacts on stream ecosystem structure and function. Ecological Applications 22(8):2144-2163.

Bradley D., and S. Ormerod. 2002. Long-term effects of catchment liming on invertebrates in upland streams. Freshwater Biology 47(1):161-171.

Brenner F. J., H. A. Gray, B. R. Porter, and V. A. Tilmans. 1995. Potential effects of mining contaminants on ecosystem function and human health. Pages 100-111 in S. K. Majumdar, E. W. Miller and F. J. Brenner, editors. Environmental contaminants, ecosystems and human health. The Pennsylvania Academy of Science, Easton, PA.

Brown B. L., C. M. Swan, D. A. Auerbach, E. H. Campbell Grant, N. P. Hitt, K. O. Maloney, and C. Patrick. 2011. Metacommunity theory as a multispecies, multiscale framework 
for studying the influence of river network structure on riverine communities and ecosystems. Journal of the North American Benthological Society 30(1):310-327.

Campbell D. 2000. Using energy systems theory to define, measure, and interpret ecological integrity and ecosystem health. Ecosystem Health 6(3):181-204.

Carlson B. 2013. Water chemistry and benthic macroinvertebrate ecology in response to acid mine drainage. Master's thesis. West Virginia University, Morgantown, WV.

Changul C., C. Sutthirat, G. Padmanahban, and C. Tongcumpou. 2010. Chemical characteristics and acid drainage assessment of mine tailings from Akara Gold mine in Thailand. Environmental Earth Sciences 60(8):1583-1595.

Coberly E. J., and R. Rice. 2013. WV AML in-stream dosing for treatment of AMD. West Virginia Department of Environmental Protection Office of Abandoned Mine Lands and Reclamation Charleston, WV.

Cushing C. E., and J. D. Allan. 2001. Streams their ecology and life. Academic Press, San Diego, CA, USA.

Emerson D. G., A. V. Vecchia, and A. L. Dahl. 2005. Evaluation of drainage-area ratio method used to estimate streamflow for the Red River of the North Basin, North Dakota and Minnesota. U.S. Geological Survey, Reston, VA.

Flory E. A., and A. M. Milner. 2000. Macroinvertebrate community succession in Wolf Point Creek, Glacier Bay National Park, Alaska. Freshwater Biology 44(3):465-480. 
Freund J. G., and J. T. Petty. 2007. Response of fish and macroinvertebrate bioassessment indices to water chemistry in a mined Appalachian watershed. Environmental Management 39(5):707-720.

Gerritsen J., J. Burton, and M. T. Barbour. 2000. A stream condition index for West Virginia wadeable streams. Tetra Tech, Inc., Owings Mills, MD.

Gore J.A. 1982. Benthic invertebrate colonization: source distance effects on community composition. Hydrobiologia 94:183-193.

Gunn J., C. Sarrazin-Delay, B. Wesolek, A. Stasko, and E. Szkokan-Emilson. 2010. Delayed recovery of benthic macroinvertebrate communities in junction Creek, Sudbury, Ontario, after the diversion of acid mine drainage. Human and Ecological Risk Assessment 16(4):901-912.

Heinrich K. K., M. R. Whiles, and C. Roy. 2014. Cascading ecological responses to an in-stream restoration project in a midwestern river. Restoration Ecology 22(1):72-80.

Hilderbrand R., A. Watts, and A. Randle. 2005. The myths of restoration ecology. Ecology and Society 10(1):19-29.

Jansson R., C. Nilsson, and B. Malmqvist. 2007. Restoring freshwater ecosystems in riverine landscapes: the roles of connectivity and recovery processes. Freshwater Biology 52(4):589-596.

Karr J. R. 1981. Assessment of biotic integrity using fish communities. Fisheries 6:91-107. 
Lake P. S., N. Bond, and P. Reich. 2007. Linking ecological theory with stream restoration. Freshwater Biology 52(4):597-615.

LeFevre S., and W. Sharpe. 2002. Acid stream water remediation using limestone sand on bear run in southwestern Pennsylvania. Restoration Ecology 10(2):223-236.

Lei L., C. Song, X. Xie, Y. Li, and F. Wang. 2010. Acid mine drainage and heavy metal contamination in groundwater of metal sulfide mine at arid territory (BS mine, Western Australia). Transactions of Nonferrous Metals Society of China 20(8):1488-1493.

Leonard P. M., and D. J. Orth. 1986. Application and testing of an index of biotic integrity in small, coolwater streams. Transactions of the American Fisheries Society 115(3):401414.

Louhi P., H. Mykrä, R. Paavola, A. Huusko, T. Vehanen, A. Mäki-Petäys, and T. Muotka. 2011. Twenty years of stream restoration in Finland: little response by benthic macroinvertebrate communities. Ecological Applications 21(6):1950-1961.

McCarthy T. 2011. The impact of acid mine drainage in South Africa. South African Journal of Science 107(5-6):1-7.

McClurg S. E., J. T. Petty, P. M. Mazik, and J. L. Clayton. 2007. Stream ecosystem response to limestone treatment in acid impacted watersheds of the Allegheny plateau. Ecological Applications 17(4):1087-1104. 
McGarigal K., S. Cushman, and S. G. Stafford. 2000. Multivariate statistics for wildlife and ecology research. Springer-Verlag, New York.

McMahon T. E. 1982. Habitat suitability index models: Creek chub. U.S.D.I. Fish and Wildlife Service. FWS/OBS-82/10.4 23 pp.

Merovich Jr G. T., J. T. Petty, M. P. Strager, and J. B. Fulton. 2013. Hierarchical classification of stream condition: A house-neighborhood framework for establishing conservation priorities in complex riverscapes. Freshwater Science 32(3):874-891.

Merovich Jr. G. T., and J. T. Petty. 2007. Interactive effects of multiple stressors and restoration priorities in a mined Appalachian watershed. Hydrobiologia 575(1):13-31.

Merovich Jr. G. T., J. M. Stiles, J. T. Petty, P. F. Ziemkiewicz, and J. B. Fulton. 2007. Water chemistry-based classification of streams and implications for restoring mined Appalachian watersheds. Environmental Toxicology and Chemistry 26(7):1361-1369.

Merriam E. R., J. T. Petty, G. T. Merovich Jr., J. B. Fulton, and M. P. Strager. 2011. Additive effects of mining and residential development on stream conditions in a central Appalachian watershed. Journal of the North American Benthological Society 30(2):399418.

Merritt R. W., K. W. Cummins, and M. B. Berg, editors. 2008. An introduction to the aquatic insects of North America. $4^{\text {th }}$ edition. Kendall/Hunt, Dubuque, IA. 
Oksanen J., F. Guillaume Blanchet, R. Kindt, P. Legendre, P. R. Minchin, R. B. O'Hara, G. L. Simpson, P. Solymos, M. Henry, H. Stevens, and H. Wagner 2013. vegan: Community Ecology Package R package version 2.0-10.

Palmer M. A., D. D. Hart, J. D. Allan, and E. Bernhardt 2003. Bridging engineering, ecological and geomorphic science to enhance riverine restoration: local and national efforts. Proceedings of A National Symposium on Urban and Rural Stream Protection and Restoration, EWRI World Water and Environmental Congress, Philadelphia, PA, June 2003, published by the American Society of Civil Engineers, Reston VA.

Palmer M. A., E. S. Bernhardt, J. D. Allan, P. S. Lake, G. Alexander, S. Brooks, J. Carr, S. Clayton, C. N. Dahm, J. F. Shah, D. L. Galat, S. G. Loss, P. Goodwin, D. D. Hart, B. Hassett, R. Jenkinson, G. M. Kondolf, R. Lave, J. L. Meyer, T. K. O'Donnell, L. Pagano, and E. Sudduth. 2005. Standards for ecologically successful river restoration. Journal of Applied Ecology 42(2):208-217.

Pandey P. K., R. Sharma, M. Roy, and M. Pandey. 2007. Toxic mine drainage from Asia's biggest copper mine at Malanjkhand, India. Environmental Geochemistry and Health 29(3):237-248.

Peckarsky B. L., P. R. Fraissinet, M. A. Penton, and D. J. Conklin. 1990. Freshwater macroinvertebrates of northeastern North America. Cornell University Press, Ithaca, NY.

Petty J. T., J. B. Fulton, M. P. Strager, G. T. Merovich Jr., J. M. Stiles, and P. F. Ziemkiewicz. 2010. Landscape indicators and thresholds of stream ecological impairment in an 
intensively mined Appalachian watershed. Journal of the North American Benthological Society 29(4):1292-1309.

Petty J. T., B. Gutta, R. Herd, J. Fulton, J. Stiles, M. Strager, J. Svetlick, and P. Ziemkiewicz 2008. Identifying cost-effective restoration strategies in mining impacted West Virginia watersheds. 25th Annual Meetings of the American Society of Mining and Reclamation and 10th Meeting of IALR 2008. Richmond, VA.

Petty J. T., P. J. Lamothe, and P. M. Mazik. 2005. Spatial and seasonal dynamics of brook trout populations inhabiting a central Appalachian watershed. Transactions of the American Fisheries Society 134(3):572-587.

Petty J. T., and D. Thorne. 2005. An ecologically based approach to identifying restoration priorities in an acid-impacted watershed. Restoration Ecology 13(2):348-357.

Pond G. J., M. E. Passmore, F. A. Borsuk, L. Reynolds, and C. J. Rose. 2008. Downstream effects of mountaintop coal mining: comparing biological conditions using family- and genus-level macroinvertebrate bioassessment tools. Journal of the North American Benthological Society 27(3):717-737.

R Development Core Team. 2013. R: A language and environment for statistical computing 3.0.2.

Roper B., and D. Scarnecchia. 1995. Observer variability in classifying habitat types in stream surveys. North American Journal of Fisheries Management 15(1):49-53. 
Rosenberg D. M., V. H. Resh, and R. S. King. 2008. Use of aquatic insects in biomonitoring. In: R. W. Merritt, K. W. Cummins, and M. Berg, editors. An introduction to the aquatic insects of North America, $4^{\text {th }}$ edition. Kendall/Hunt, Dubuque, IA.

Sarmiento A. M., A. DelValls, J. Miguel Nieto, M. J. Salamanca, and M. A. Caraballo. 2011. Toxicity and potential risk assessment of a river polluted by acid mine drainage in the Iberian Pyrite Belt (SW Spain). The Science of the Total Environment 409(22):47634771.

Simmons J. A., E. R. Lawrence, and T. G. Jones. 2005. Treated and untreated acid mine drain effects on stream periphyton biomass, leaf decomposition, and macroinvertebrate diversity. Journal of Freshwater Ecology 20(3):413-424.

Simon M. L., D. S. Cherry, R. J. Currie, and C. E. Zipper. 2012. The ecotoxicological recovery of Ely Creek and tributaries (Lee County, VA) after remediation of acid mine drainage. Environmental Monitoring and Assessment 184(4):2559-2574.

Skousen J. G. 1995. Acid mine drainage. Acid mine drainage: control and treatment. West Virginia University and the National Land Mine Reclamation Center, Morgantown, WV.

Strager M. P., J. T. Petty, and J. M. Strager. 2009. A spatially explicit framework for quantifying downstream hydrologic conditions. Journal of Environmental Management 90(5):1854.

Strosnider W. H. J., F. S. Llanos López, and R. W. Nairn. 2011. Acid mine drainage at Cerro Rico de Potosí II: severe degradation of the Upper Rio Pilcomayo watershed. Environmental Earth Sciences 64(4):911-923. 
TU (Trout Unlimited). 2011. The west branch Susquehanna recovery benchmark project. Trout Unlimited's Eastern Abandoned Mine Program, Lock Haven, PA.

United States Environmental Protection Agency (USEPA). 2000. Mid-Atlantic Highlands streams assessment: final report / by Environmental Monitoring and Assessment Program, National Health and Environmental Effects Research Laboratory, Western Ecology Division, Office of Research and Development \& Region III. Philadelphia, PA.

Vieira N. K. M., W. H. Clements, L. S. Guevara, and B. F. Jacobs. 2004. Resistance and resilience of stream insect communities to repeated hydrologic disturbances after a wildfire. Freshwater Biology 49(10):1243-1259.

West Virginia Water Research Institute (WVWRI), National Mine Land Reclamation Center, Watershed Technical Assistance Center, and West Virginia University. 2007. Abram Creek watershed restoration plan. West Virginia University Morgantown, WV.

Winking C., A. W. Lorenz, B. Sures, and D. Hering. 2014. Recolonisation patterns of benthic invertebrates: a field investigation of restored former sewage channels. Freshwater Biology 59(9):1932-1944.

WVDEP (West Virginia Department of Environmental Protection). 2013. Benthic invertebrate sampling, processing, and analysis: standard operating procedures. West Virginia Division of Environmental Protection Charleston, WV. 
Zuellig R. E., B. C. Kondratieff, and H. A. Rhodes. 2002. Benthos recovery after an episodic sediment release into a Colorado rocky mountain river. Western North American Naturalist 62(1):59-72. 
Figures and Tables

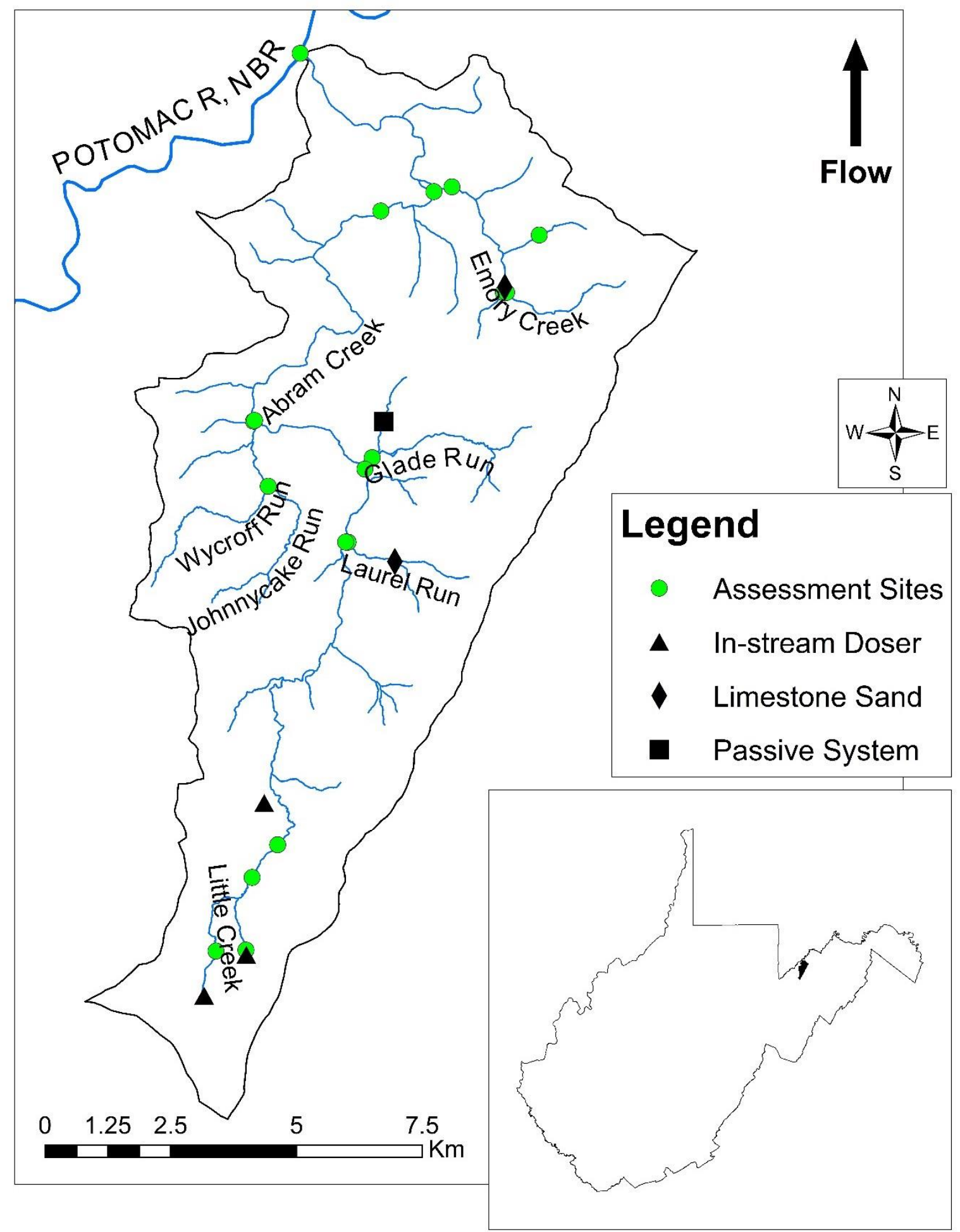

Figure 1. Map of Abram Creek watershed in West Virginia's eastern panhandle along with AMD-treatment locations and assessment sites. 


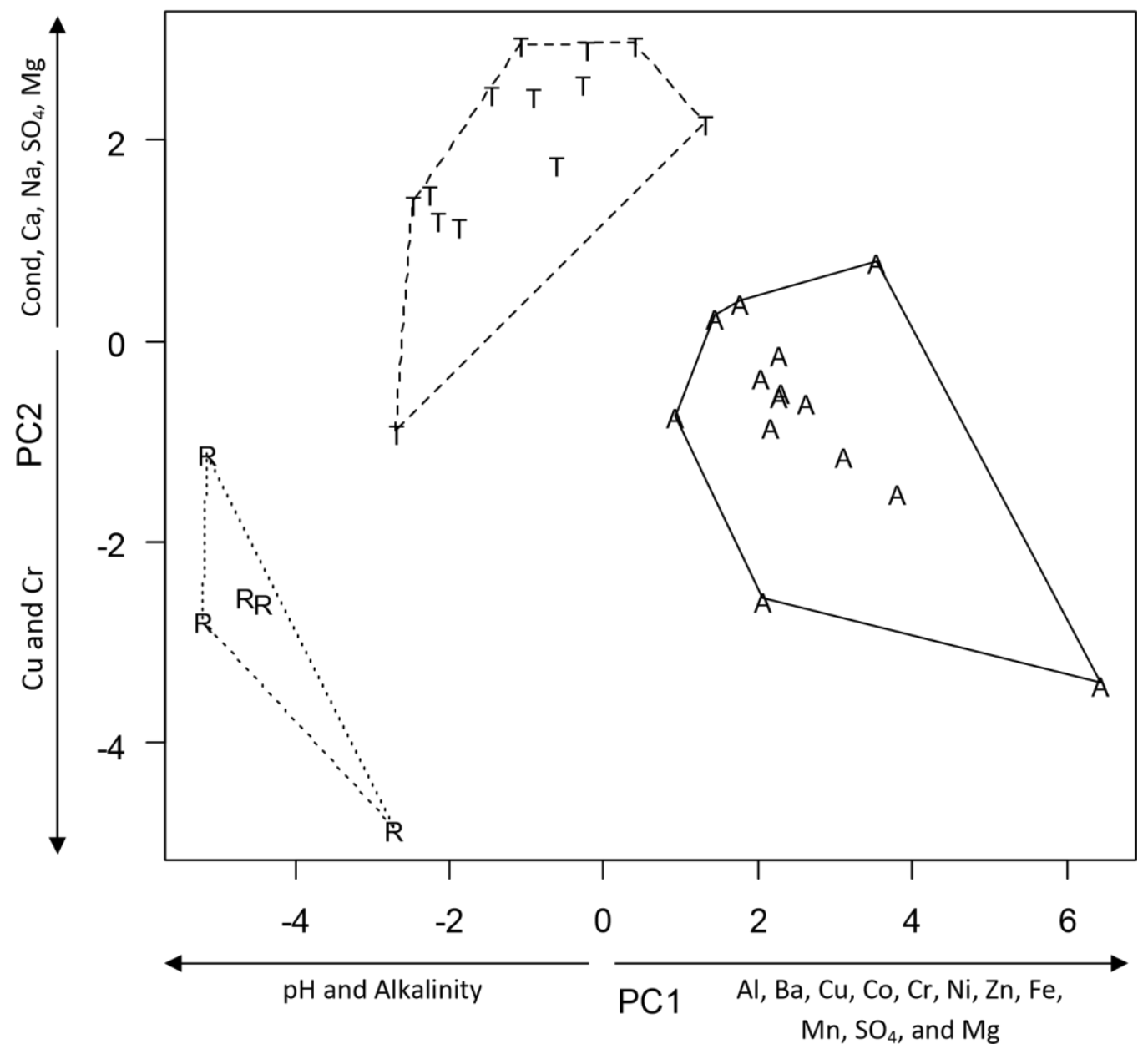

Figure 2. Bivariate scatter plot of principle component (PC) 1 and 2 scores for each water chemistry sample overlaid with stream type. $\mathrm{A}=$ acid mine drainage (AMD), $\mathrm{T}=$ treated, and $\mathrm{R}$ $=$ reference stream types. Chemical parameters with high $(>|0.5|)$ factor loadings on each PC are shown on the corresponding axis. $\mathrm{SO}_{4}=$ sulfate; Cond $=$ specific conductivity. 

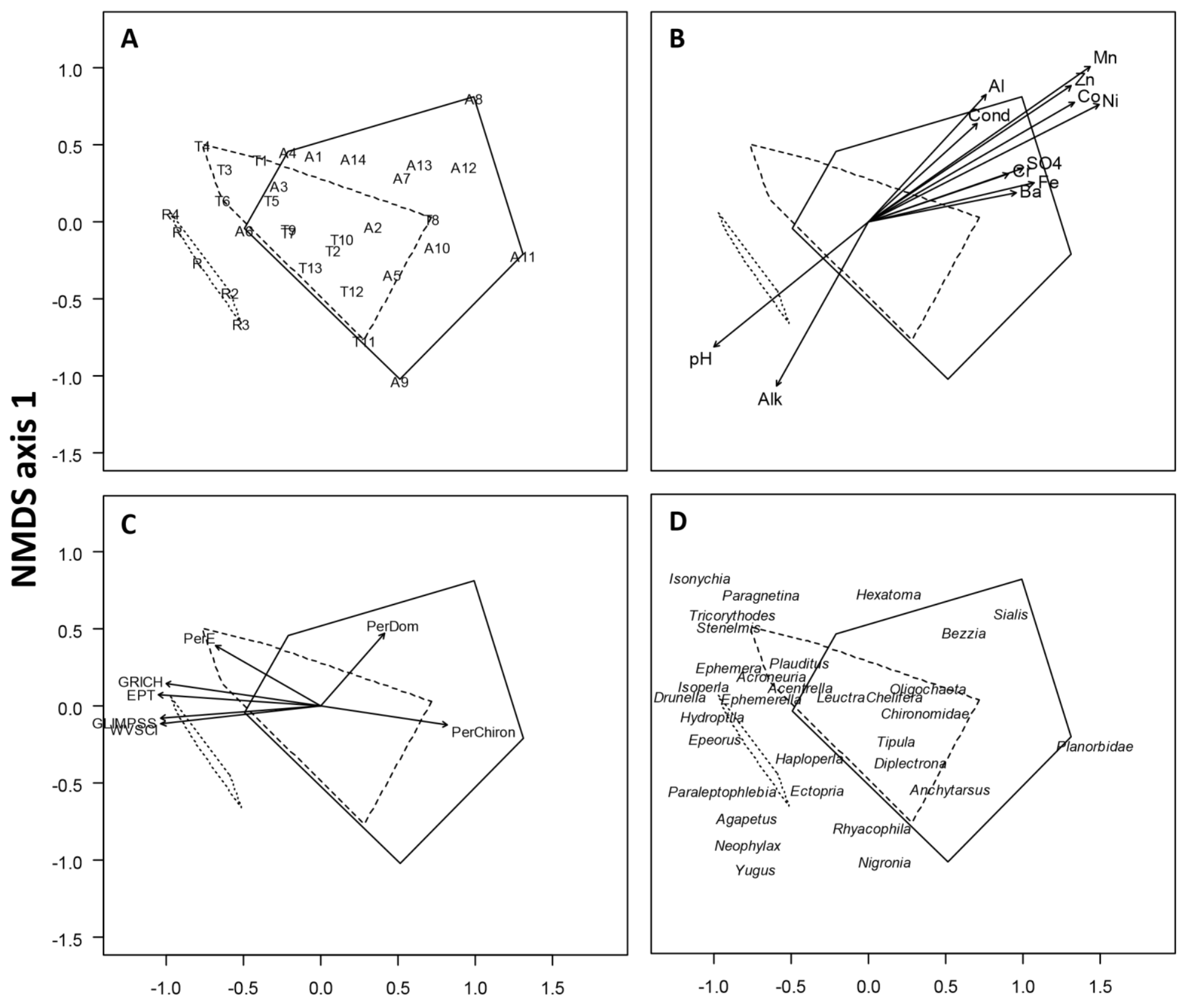

NMDS axis 2

Figure 3. Nonmetric multidimensional scaling (NMDS) ordination of benthic macroinvertebrate samples (Bray-Curtis distance coefficient) in 2 dimensions showing sites labeled by stream type (A), water chemistry vectors (B), macroinvertebrate metrics (C), and weighted mean positions of selected taxa (D). Stress $=0.15$ in the 3-dimensional solution. Stream type abbreviations as in Fig. 2. Alk = alkalinity, Cond $=$ specific conductivity, PerDom $=\%$ dominance, $P$ PerE $=\%$ Ephemeroptera, PerChiron $=\%$ Chironomidae, EPT $=$ Ephemeroptera, Plecoptera, Trichoptera, GRICH = genus-level richness, WVSCI = West Virginia Stream Condition Index (a family-level multimetric index of biotic integrity), GLIMPSS = Genus Level Index of Most Probable Stream Status (a genus-level multimetric index of biotic integrity). ADONIS p-value $=0.004$. 


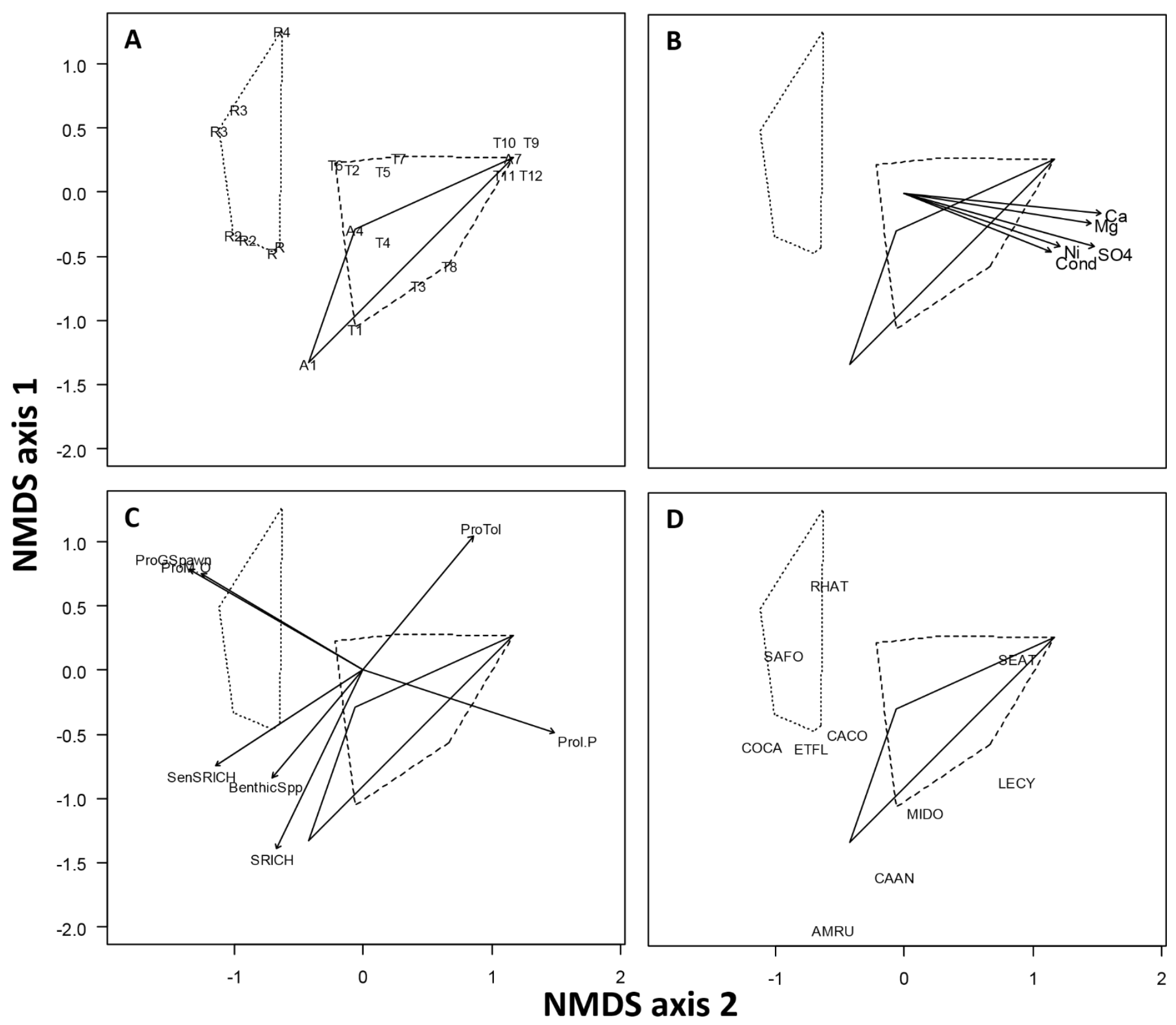

Figure 4. Nonmetric multidimensional scaling (NMDS) ordination of fish samples (Bray-Curtis distance coefficient) in 2 dimensions showing sites labeled by stream type (A), water chemistry vectors (B), fish metrics (C), and weighted mean positions of selected species (D). Stress $=0.11$ in the 2-dimensional solution. Stream type abbreviations as in Fig. 2. Cond = specific conductivity, BenthicSpp $=$ \# of benthic species, ProTol $=$ proportion tolerant, $\mathrm{SRICH}=$ specieslevel richness. SenSRICH = sensitive species richness, ProI.P = proportion of invertivorepiscivores, ProM.O = proportion of macro-omnivores, ProGSpawn = proportion of gravel spawning species, SEAT $=$ Semotilus atromaculatus $($ creek chub), SAFO $=$ Salvelinus fontinalis (brook trout), ETFL = Etheostoma flabellare (fantail darter), $\mathrm{COCA}=$ Cottus caeruleomentum (blue ridge sculpin), RHAT $=$ Rhinichthys atratulus (eastern blacknose dace), CACO = Catostomus commersonii (white sucker), LECY = Lepomis cyanellus (green sunfish), MIDO = Micropterus dolomieu (smallmouth bass), CAAN = Campostoma anomalum (stoneroller), $\mathrm{AMRU}=$ Ambloplites rupestris (rock bass). ADONIS p-value $=0.001$. 


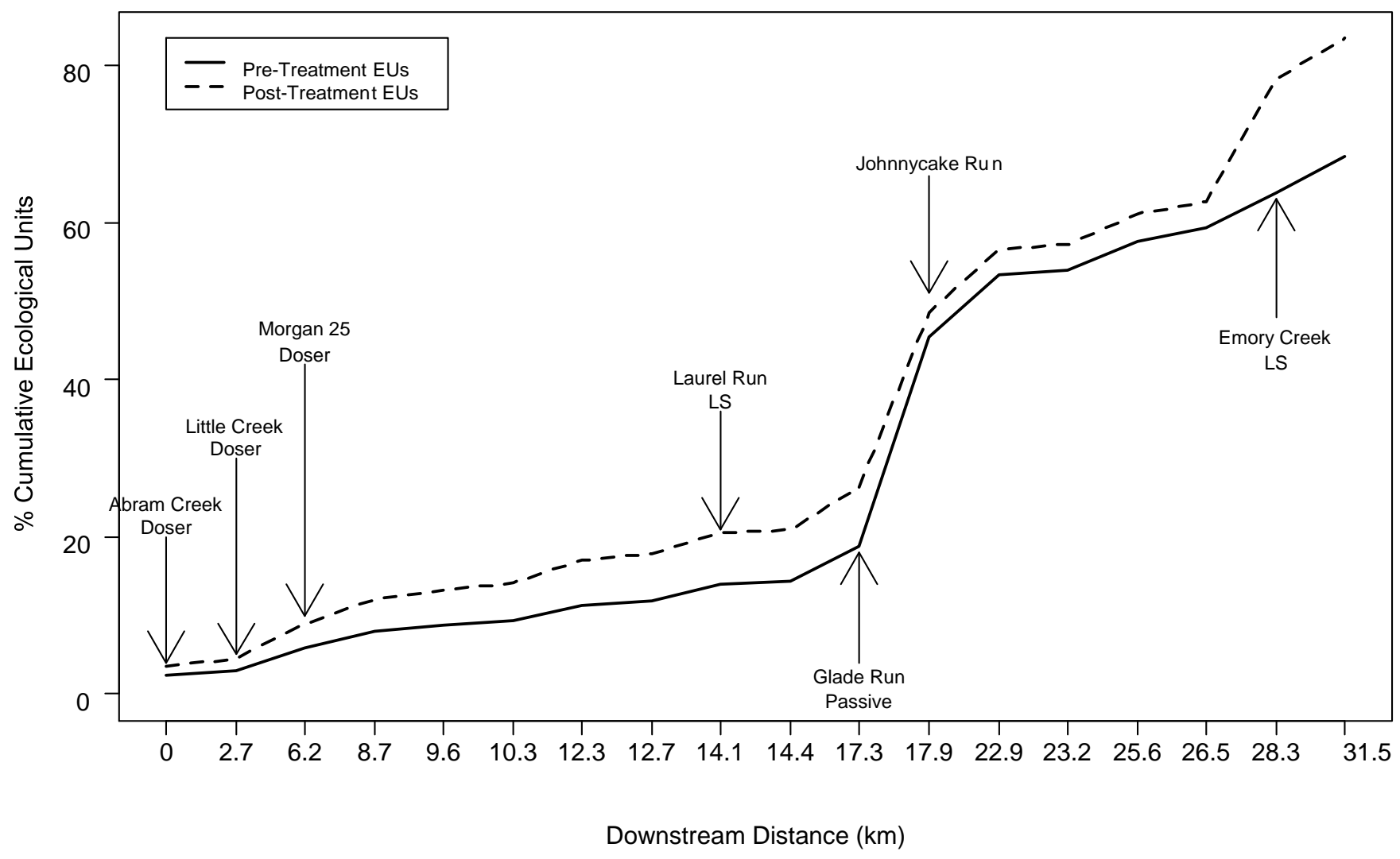

Figure 5. Percent cumulative EUs along the Abram Creek mainstem from the headwaters to the mouth pre- (2008) and post-treatment (2013). Arrows represent major tributaries entering the mainstem at their respective river kilometer and treatment type. 


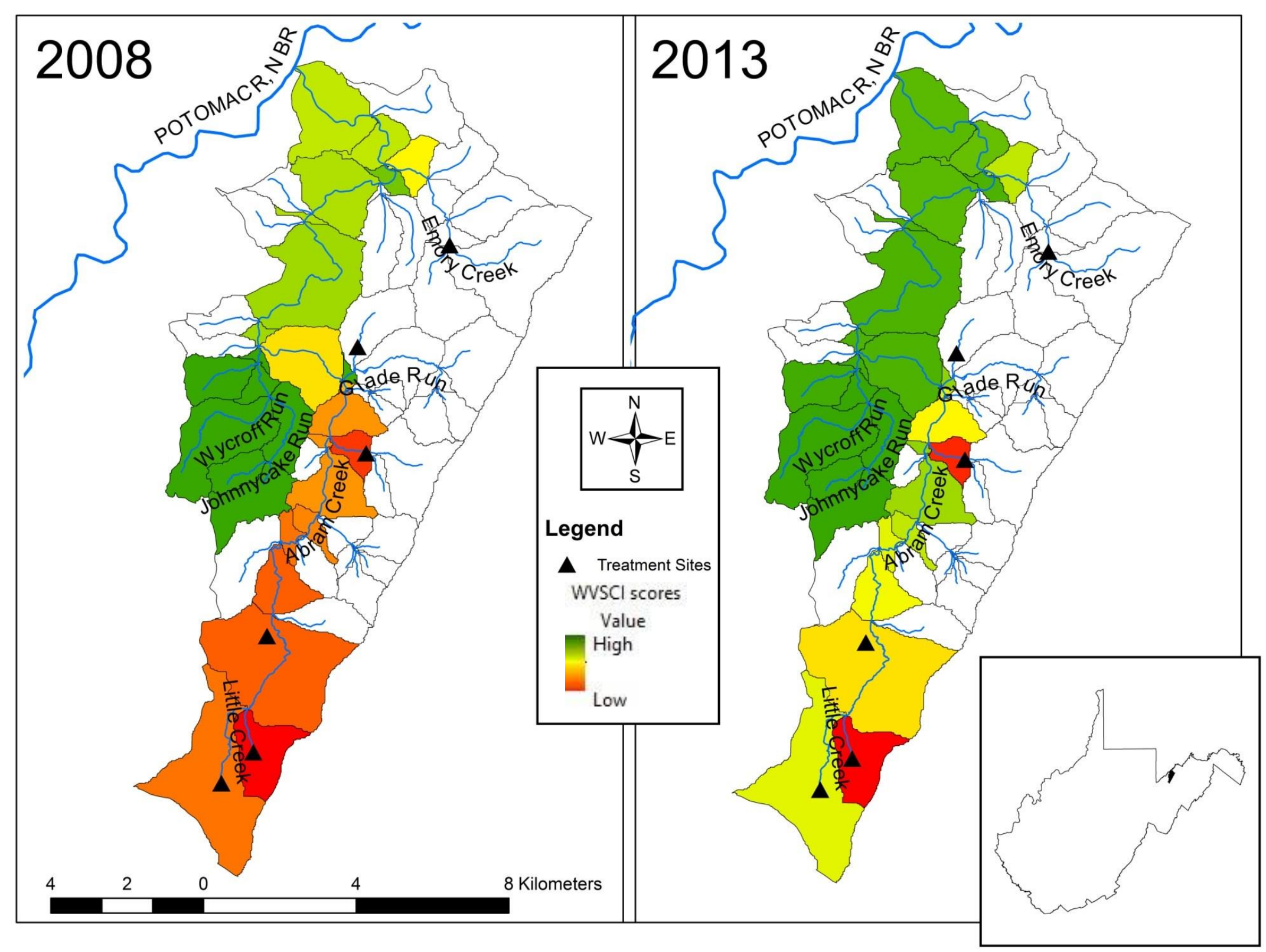

Figure 6. Map illustrating segment-level watershed WVSCI scores pre- (2008) and post-treatment (2013) throughout the Abram Creek watershed. 
Table 1. Site names, site abbreviations, GPS coordinates of sampling locations, stream type, and treatment technology implemented. “_“= na, L.S. Sand = limestone sand, I.S. Doser = in-stream doser.

\begin{tabular}{|c|c|c|c|c|c|c|}
\hline Site Name & Site Abbrev. & Latitude & Longitude & $\begin{array}{c}\text { Stream Type } \\
2008\end{array}$ & $\begin{array}{c}\text { Stream Type } \\
2013\end{array}$ & $\begin{array}{c}\text { Treatment } \\
\text { Type }\end{array}$ \\
\hline Abram Creek at Mouth & AB MOUTH & 39.37938 & -79.20199 & AMD & Treated & - \\
\hline Abram Creek above Emory & AB ABV EM & 39.35369 & -79.17154 & AMD & Treated & - \\
\hline Emory Creek at Mouth & EMORY & 39.35429 & -79.16722 & AMD & Treated & L.S. Sand \\
\hline Unnamed Tributary 2 Emory Creek & UNT EMORY 2 & 39.33565 & -79.15524 & - & Reference & - \\
\hline Emory Creek Headwater Right Fork & EM HW RF & 39.33565 & -79.15599 & - & Reference & - \\
\hline Emory Creek Headwater Left Fork & EM HW LF & 39.33565 & -79.15524 & - & AMD & - \\
\hline Abram Creek at Laytons & AB LAT & 39.35058 & -79.18403 & AMD & Treated & - \\
\hline Johnnycake Run at Mouth & JC MOUTH & 39.31358 & -79.21424 & Reference & Reference & - \\
\hline Upper Johnnycake Run & JC UPPER & 39.30171 & -79.21109 & - & Reference & - \\
\hline Abram Creek above Johnnycake & AB ABV JC & 39.31370 & -79.21385 & AMD & Treated & - \\
\hline Glade Run at Mouth & GLADE & 39.30629 & -79.18667 & AMD & Treated & Passive \\
\hline Abram Creek above Glade & AB ABV GLD & 39.30453 & -79.18884 & AMD & Treated & - \\
\hline Laurel Run at Mouth & LAUREL & 39.29607 & -79.19072 & AMD & Treated & L.S. Sand \\
\hline Abram Creek above Laurel & AB ABV LAURL & 39.29654 & -79.19087 & AMD & Treated & - \\
\hline Abram Creek at Vindex & AB VIN & 39.23752 & -79.21071 & AMD & Treated & - \\
\hline Abram Creek at CR 42 & AB AT 42 & 39.23161 & -79.21660 & AMD & Treated & - \\
\hline Little Creek & AB HW LF & 39.21851 & -79.21824 & AMD & Treated & I.S. Doser \\
\hline Abram Creek Headwaters & AB HW RF & 39.21855 & -79.22520 & AMD & Treated & I.S. Doser \\
\hline
\end{tabular}


Table 2. Means and standard deviations of water chemistry parameters and principal component (PC) 1,2, 3, and 4 scores for each stream type. Water chemistry constituent means with different letters are statistically different from one another $(\mathrm{p}<0.05$; analysis of variance, Tukeys posttest). Means are reported in $\mathrm{mg} / \mathrm{L}$. Conductivity is reported in $\mu \mathrm{S} / \mathrm{cm}$, and alkalinity is reported in $\mathrm{mg} / \mathrm{L} \mathrm{CaCO} 3$ equivalents.

\begin{tabular}{|c|c|c|c|c|c|c|}
\hline & \multicolumn{6}{|c|}{ Stream Type } \\
\hline & \multicolumn{2}{|c|}{$\operatorname{AMD}(n=14)$} & \multicolumn{2}{|c|}{ Treated $(n=13)$} & \multicolumn{2}{|c|}{ Reference $(n=4)$} \\
\hline & Mean & SD & Mean & SD & Mean & SD \\
\hline $\mathrm{pH}$ & $6.25^{a}$ & 0.74 & $7.02^{b}$ & 0.45 & $7.29^{b}$ & 0.42 \\
\hline Conductivity & $313.93^{a}$ & 69.59 & $386.85^{a}$ & 90.40 & $118.8^{b}$ & 68.69 \\
\hline Alkalinity & $4.03^{a}$ & 3.39 & $15.31^{\mathrm{b}}$ & 7.84 & $24.57^{b}$ & 13.75 \\
\hline $\mathrm{Al}$ & $0.47^{a}$ & 0.82 & $0.03^{b}$ & 0.04 & $0.01^{b}$ & 0.01 \\
\hline $\mathrm{Ba}$ & $0.07^{a}$ & 0.02 & $0.03^{b}$ & 0.00 & $0.04^{b}$ & 0.01 \\
\hline $\mathrm{Cu}$ & $0.01^{a}$ & 0.00 & $0.01^{b}$ & 0.00 & $0.01^{b}$ & 0.00 \\
\hline $\mathrm{Cl}$ & 4.35 & 2.32 & 5.05 & 2.82 & 6.45 & 4.89 \\
\hline Co & $0.06^{\mathrm{a}}$ & 0.04 & $0.01^{\mathrm{b}}$ & 0.01 & $0.01^{b}$ & 0.00 \\
\hline $\mathrm{Cr}$ & $0.02^{a}$ & 0.01 & $0.00^{b}$ & 0.00 & $0.01^{b}$ & 0.01 \\
\hline $\mathrm{Ca}$ & $26.35^{\mathrm{a}}$ & 6.21 & $39.41^{\mathrm{a}}$ & 16.26 & $11.55^{b}$ & 4.80 \\
\hline $\mathrm{Na}$ & 3.88 & 1.88 & 5.72 & 1.63 & 3.86 & 2.76 \\
\hline $\mathrm{Ni}$ & $0.05^{\mathrm{a}}$ & 0.03 & $0.03^{b}$ & 0.01 & $0.01^{\mathrm{c}}$ & 0.00 \\
\hline $\mathrm{Se}$ & 0.06 & 0.05 & 0.03 & 0.00 & 0.04 & 0.01 \\
\hline $\mathrm{Zn}$ & $0.10^{a}$ & 0.07 & $0.03^{b}$ & 0.03 & $0.01^{c}$ & 0.00 \\
\hline $\mathrm{SO}_{4}$ & $113.11^{\mathrm{a}}$ & 30.62 & $136.61^{\mathrm{a}}$ & 61.13 & $11.48^{\mathrm{b}}$ & 1.50 \\
\hline $\mathrm{Fe}$ & $0.51^{\mathrm{a}}$ & 0.81 & $0.09^{b}$ & 0.15 & $0.03^{b}$ & 0.00 \\
\hline $\mathrm{Mg}$ & $9.23^{a}$ & 1.94 & $12.29^{a}$ & 5.39 & $2.35^{b}$ & 0.57 \\
\hline $\mathrm{Mn}$ & $1.82^{\mathrm{a}}$ & 1.15 & $0.73^{b}$ & 0.48 & $0.01^{c}$ & 0.00 \\
\hline PC1 & $2.62^{\mathrm{a}}$ & 1.34 & $-1.11^{b}$ & 1.21 & $-4.44^{c}$ & 1.01 \\
\hline PC2 & $-0.77^{a}$ & 1.13 & $1.89^{b}$ & 1.07 & $-2.77^{c}$ & 1.34 \\
\hline PC3 & -0.25 & 1.57 & 0.20 & 0.83 & 0.17 & 0.98 \\
\hline PC4 & 0.23 & 1.27 & -0.20 & 0.88 & -0.13 & 0.69 \\
\hline
\end{tabular}


Table 3. Acid, alkalinity, and net acidity loads pre- (2008) and post-treatment (2013) at the mouth of the watershed and major tributaries that received treatment (values in tons/yr $\mathrm{CaCO}_{3}$ equivalents). $\Delta$ net acidity negative values indicate decline.

\begin{tabular}{|c|c|c|c|c|c|c|c|}
\hline \multirow[b]{2}{*}{ Site } & \multirow[b]{2}{*}{$\begin{array}{l}\text { Acid } \\
\text { Load }\end{array}$} & \multirow{2}{*}{$\begin{array}{c}2008 \\
\begin{array}{c}\text { Alkalinity } \\
\text { Load }\end{array}\end{array}$} & \multirow[b]{2}{*}{$\begin{array}{c}\text { Net } \\
\text { Acidity }\end{array}$} & \multirow[b]{2}{*}{$\begin{array}{l}\text { Acid } \\
\text { Load }\end{array}$} & \multirow{2}{*}{$\begin{array}{c}2013 \\
\text { Alkalinity } \\
\text { Load }\end{array}$} & \multirow[b]{2}{*}{$\begin{array}{c}\text { Net } \\
\text { Acidity }\end{array}$} & \multirow[b]{2}{*}{$\begin{array}{l}\Delta \text { Net } \\
\text { Acidity }\end{array}$} \\
\hline & & & & & & & \\
\hline $\begin{array}{c}\text { Abram Creek at } \\
\text { Mouth }\end{array}$ & 227.99 & 330.33 & -102.34 & 34.33 & 1156.29 & -1121.96 & -1019.62 \\
\hline Emory Creek & 130.43 & 30.19 & 100.24 & 34.36 & 154.36 & -120 & -220.25 \\
\hline Glade Run & 13.59 & 11.37 & 2.21 & 4.1 & 118.66 & -114.57 & -116.78 \\
\hline Laurel Run & 41.36 & 36 & 5.36 & 39.24 & 18.23 & 21.01 & 15.64 \\
\hline Little Creek & 56.84 & 3.55 & 53.28 & 1.14 & 74.46 & -73.33 & -126.61 \\
\hline Abram Creek HW & 25.59 & 0 & 25.59 & 2.42 & 78.43 & -76.01 & -101.59 \\
\hline
\end{tabular}


Table 4. Means and standard deviations of benthic macroinvertebrate and fish metrics for each stream type. Metric means with different letters are statistically different from one another ( $\mathrm{p}<$ 0.05; analysis of variance, Tukeys post-test). WVSCI = West Virginia Stream Condition Index, GLIMPSS = Genus Level Index of Most Probable Stream Status, EPT = Ephemeroptera, Plecoptera, Trichoptera, I-P = Invertivore-Piscivore.

\begin{tabular}{|c|c|c|c|c|c|c|}
\hline & \multicolumn{6}{|c|}{ Water Quality Type } \\
\hline & \multicolumn{2}{|c|}{$\operatorname{AMD}(n=14)$} & \multicolumn{2}{|c|}{ Treated $(n=13)$} & \multicolumn{2}{|c|}{ Reference $(n=4)$} \\
\hline & Mean & SD & Mean & SD & Mean & SD \\
\hline WVSCl & $47.75^{\mathrm{a}}$ & 17.64 & $67.39^{b}$ & 13.76 & $85.17^{\mathrm{b}}$ & 1.95 \\
\hline GLIMPSS & $26.03^{a}$ & 15.07 & $41.50^{b}$ & 14.18 & $66.70^{c}$ & 6.82 \\
\hline EPT Genus Richness & $5.36^{\mathrm{a}}$ & 4.75 & $9.85^{b}$ & 4.56 & $9.85^{c}$ & 3.96 \\
\hline Genus Richness & $13.00^{\mathrm{a}}$ & 7.68 & $19.23^{\mathrm{ab}}$ & 7.70 & $27.40^{b}$ & 1.52 \\
\hline \% EPT Families & $28.87^{a}$ & 25.28 & $59.13^{b}$ & 23.00 & $61.75^{b}$ & 8.94 \\
\hline \% Chironomidae & $45.68^{\mathrm{a}}$ & 18.44 & $25.95^{\mathrm{b}}$ & 17.65 & $21.11^{\mathrm{b}}$ & 4.39 \\
\hline$\%$ 2Dominant & $66.24^{\mathrm{a}}$ & 12.78 & $61.20^{\mathrm{a}}$ & 12.08 & $44.40^{b}$ & 11.13 \\
\hline Fish Species Richness & $0.73^{\mathrm{a}}$ & 1.75 & $2.77^{b}$ & 1.96 & $3.75^{b}$ & 2.43 \\
\hline \# of Benthic Species & $0.00^{\mathrm{a}}$ & 0.00 & $0.08^{a}$ & 0.28 & $0.50^{\mathrm{b}}$ & 0.53 \\
\hline Sensitive Species Richness & $0.13^{\mathrm{a}}$ & 0.35 & $0.23^{\mathrm{a}}$ & 0.44 & $0.75^{\mathrm{b}}$ & 0.46 \\
\hline Proportion of Tolerant Individuals & $0.17^{\mathrm{a}}$ & 0.36 & $0.86^{b}$ & 0.28 & $0.78^{\mathrm{b}}$ & 0.22 \\
\hline Proportion of I-P Individuals & $0.15^{\mathrm{a}}$ & 0.33 & $0.61^{b}$ & 0.33 & $0.13^{\mathrm{a}}$ & 0.12 \\
\hline Proportion of Macro-Omnivores & $0.05^{\mathrm{a}}$ & 0.15 & $0.31^{b}$ & 0.28 & $0.71^{\mathrm{c}}$ & 0.25 \\
\hline Proportion of Gravel Spawning Species & $0.05^{\mathrm{a}}$ & 0.13 & $0.32^{\mathrm{b}}$ & 0.30 & $0.76^{c}$ & 0.26 \\
\hline
\end{tabular}


Table 5. EUs downstream of treatment sites, and at the mouth of the watershed before and after project completion.

\begin{tabular}{ccc}
\hline \hline & \multicolumn{2}{c}{ Ecological Units $(\mathrm{km})$} \\
\cline { 2 - 3 } Site & 2008 & 2013 \\
\hline Abram Creek HW & 1.1 & 2.0 \\
Little Creek HW & 0.3 & 0.5 \\
Morgan 25 & 1.4 & 2.4 \\
Laurel Run at Mouth & 0.4 & 0.6 \\
Glade Run at Mouth & 0.5 & 0.4 \\
Emory Creek at Mouth & 0.8 & 1.0 \\
Abram Creek at Mouth & 2.3 & 2.9 \\
\hline
\end{tabular}

